\title{
DJ-1/PARK7 Impairs Bacterial Clearance in Sepsis
}

\author{
Hajera Amatullah ${ }^{1,2}$, Yuexin Shan ${ }^{1}$, Brittany L. Beauchamp ${ }^{3}$, Patricia L. Gali ${ }^{1}$, Sahil Gupta ${ }^{1,4}$, \\ Tatiana Maron-Gutierrez ${ }^{5,6}$, Edwin R. Speck ${ }^{1}$, Alison E. Fox-Robichaud ${ }^{7}$, Jennifer L. Y. Tsang ${ }^{1,8}$, Shirley H. J. Mei ${ }^{9}$, \\ Tak W. Mak ${ }^{10}$, Patricia R. M. Rocco ${ }^{6}$, John W. Semple ${ }^{1}$, Haibo Zhang ${ }^{1}$, Pingzhao Hu ${ }^{11}$, John C. Marshall ${ }^{1}$, \\ Duncan J. Stewart ${ }^{9}$, Mary-Ellen Harper ${ }^{3}$, Patricia C. Liaw ${ }^{8}$, W. Conrad Liles ${ }^{12}$, and Claudia C. dos Santos ${ }^{1,4}$; on behalf \\ of the Canadian Critical Care Translational Biology Group
}

${ }^{1}$ The Keenan Research Centre for Biomedical Science of the Li Ka Shing Knowledge Institute of St. Michael's Hospital, Toronto, Ontario, Canada; ${ }^{2}$ Department of Physiology, Faculty of Medicine, and ${ }^{4}$ Institute of Medical Sciences, University of Toronto, Toronto, Ontario, Canada; ${ }^{3}$ Department of Biochemistry, Microbiology and Immunology, Faculty of Medicine, and ${ }^{9}$ Ottawa Hospital Research Institute, University of Ottawa, Ottawa, Ontario, Canada; ${ }^{5}$ Laboratory of Immunopharmacology, Oswaldo Cruz Institute, Fiocruz, Rio de Janeiro, Brazil; 'Laboratory of Pulmonary Investigation, Carlos Chagas Filho Institute of Biophysics, Federal University of Rio de Janeiro, Rio de Janeiro, Brazil; 'Thrombosis and Atherosclerosis Research Institute, Department of Medicine, McMaster University, Hamilton, Ontario, Canada; ${ }^{8}$ Department of Medicine, McMaster University, Hamilton (Niagara Campus), Ontario, Canada; ${ }^{10}$ Department of Medical Biophysics and Immunology, The Campbell Family Institute for Breast Cancer Research at Princess Margaret Hospital, Ontario Cancer Institute, University Health Network, Toronto, Ontario, Canada; ${ }^{11}$ Department of Biochemistry and Medical Genetics, University of Manitoba, Winnipeg, Manitoba, Canada; and ${ }^{12}$ Department of Medicine, University of Washington, Seattle, Washington

\section{Abstract}

Rationale: Effective and rapid bacterial clearance is a fundamental determinant of outcomes in sepsis. DJ-1 is a well-established reactive oxygen species (ROS) scavenger.

Objectives: Because cellular ROS status is pivotal to inflammation and bacterial killing, we determined the role of DJ-1 in bacterial sepsis.

Methods: We used cell and murine models with gain- and loss-offunction experiments, plasma, and cells from patients with sepsis.

Measurements and Main Results: Stimulation of bone marrow-derived macrophages (BMMs) with endotoxin resulted in increased DJ-1 mRNA and protein expression. Cellular and mitochondrial ROS was increased in DJ-1-deficient $\left({ }^{-/-}\right)$BMMs compared with wild-type. In a clinically relevant model of polymicrobial sepsis (cecal ligation and puncture), DJ-1 ${ }^{-1-}$ mice had improved survival and bacterial clearance. DJ-1 ${ }^{-1-}$ macrophages exhibited enhanced phagocytosis and bactericidal activity in vitro, and adoptive transfer of DJ-1 ${ }^{-/-}$bone marrow-derived mononuclear cells rescued wild-type mice from cecal ligation and puncture-induced mortality. In stimulated BMMs, DJ-1 inhibited ROS production by binding to $\mathrm{p} 47^{\text {phox }}$, a critical component of the NADPH oxidase complex, disrupting the complex and facilitating Nox2 (gp91 ${ }^{\text {phox }}$ ) ubiquitination and degradation. Knocking down DJ-1 (siRNA) in THP-1 (human monocytic cell line) and polymorphonuclear cells from patients with sepsis enhanced bacterial killing and respiratory burst. DJ-1 protein levels were elevated in plasma from patients with sepsis. Higher levels of circulating DJ-1 were associated with increased organ failure and death.

Conclusions: These novel findings reveal DJ-1 impairs optimal ROS production for bacterial killing with important implications for host survival in sepsis.

Keywords: DJ-1/PARK7; reactive oxygen species; sepsis; bacterial clearance; NADPH oxidase

(Received in original form April 9, 2016; accepted in final form October 11, 2016)

Supported by the Canadian Institutes of Health Research (MOP-130331 and OCN 126573; C.C.d.S.), the Early Research Award from the Ministry of Research and Innovation (ER 10-07-182; C.C.d.S.), the Ontario Graduate Scholarship (H.A.), and St. Michael's Hospital Li Ka Shing Knowledge Institute Graduate Scholarship (H.A.). The funders had no role in study design, data collection and analysis, decision to publish, or preparation of the manuscript.

Author Contributions: Conception and design, C.C.d.S., W.C.L., and J.C.M. Analysis and interpretation, H.A., B.L.B., P.L.G., Y.S., S.G., T.M.-G., E.R.S., A.E.F.-R., J.L.Y.T., S.H.J.M., T.W.M., P.R.M.R., J.W.S., P.H., and P.C.L. Drafting the manuscript for important intellectual content, H.A., J.C.M., W.C.L., D.J.S., M.-E.H., P.C.L., H.Z., and C.C.d.S.

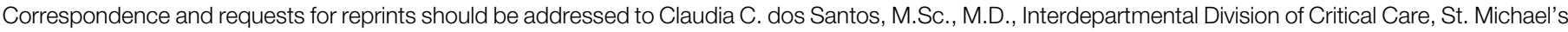
Hospital/University of Toronto, 30 Bond Street, Room 4-008, Toronto, ON, M5B 1WB Canada. E-mail: dossantosc@smh.ca

This article has an online supplement, which is accessible from this issue's table of contents at www.atsjournals.org

Am J Respir Crit Care Med Vol 195, Iss 7, pp 889-905, Apr 1, 2017

Copyright @ 2017 by the American Thoracic Society

Originally Published in Press as DOI: 10.1164/rccm.201604-07300C on October 13, 2016

Internet address: www.atsjournals.org 


\section{At a Glance Commentary}

\section{Scientific Knowledge on the}

Subject: Cellular redox status plays a complex and dynamic role in host innate immune regulation in sepsis. DJ-1 (PARK7) is a well-established antioxidant with a protective role in the nervous system. Mutations in PARK7 result in autosomal-recessive familial Parkinson disease. There is emerging evidence that DJ-1 can also modulate immune signaling pathways; however, the role of DJ-1 in sepsis remains largely uninvestigated.

\section{What This Study Adds to the}

Field: DJ-1 expression increases after cecal ligation and perforation-induced sepsis. Targeted deletion of DJ-1 in mice resulted in increased reactive oxygen species and proinflammatory markers and surprisingly improved survival in polymicrobial sepsis. These findings are similar to those observed for other deletion studies involving negative immune regulators. Our novel findings reveal that DJ-1 expression impairs reactive oxygen species production and bacterial clearance in sepsis. A robust innate immune response is vital for resolution of infection and subsequent host survival. Our findings are in line with the most recent sepsis-3 definition, which emphasizes the importance of a dysregulated host response to infection as a critical determinant of outcomes.

Sepsis with accompanying organ dysfunction remains one of the leading causes of morbidity and mortality in intensive care units (1). Despite recent advances, no specific therapies are available to reduce the burden of illness $(2,3)$. Traditional approaches including resuscitation, antibiotics, source control, and supportive care have improved outcomes $(4,5)$, whereas strategies to blunt the inflammatory response have failed to improve survival $(6,7)$.

Alternative strategies that enhance host defenses have recently gained attention (8). Our group has used systemic administration of bone marrow-derived mesenchymal stem/stromal cells to reduce inflammation, organ dysfunction, and mortality, while enhancing bacterial clearance in experimental models of polymicrobial sepsis (9-13). Network analysis of global transcriptional responses modulated by mesenchymal stem cell administration in sepsis identified the Kyoto Encyclopedia of Genes and Genomes-Parkinson's Disease pathway as markedly altered in septic tissues (14). Here we pursue one of the statistically significant gene products modulated in this pathway, Parkinson disease (autosomal recessive, early onset) 7 (PARK7), also known as DJ-1.

Originally identified as an oncogene (15), DJ-1 functions as a ubiquitous cytoprotective protein with diverse functions including transcriptional and mitochondrial regulation (16-22). Its main role, however, is providing protection from oxidative stress $(15,16)$. Loss of functional protein results in autosomal-recessive familial Parkinson disease $(23,24)$. In the case of sporadic disease, overwhelming and/or persistent oxidative stress results in loss of DJ-1 function, accumulation of reactive oxygen species (ROS), and eventual neuronal death (25-27). A recent report has questioned the role of DJ-1 as an antioxidant suggesting that rather than reducing ROS, DJ-1 is required for increased ROS production in sepsis (28).

Cellular redox status plays a complex and dynamic role in host innate immune regulation and survival in sepsis. Although excessive ROS can contribute to cell and tissue injury, free oxygen radicals and their oxidized substrates are key signaling molecules involved in pathogen recognition and clearance (29-32). Although little is known about the role of DJ-1 outside the nervous system, DJ-1-deficient Caenorhabditis elegans develop marked p38 mitogen-activated protein kinase activation and enhanced pattern recognition receptor expression (33). Moreover, increased respiratory burst occurs in DJ-1-deficient Litopenaeus vannamei after bacterial challenge (34). These data suggest a conserved and protective role for DJ-1 to minimize inflammation (ROS) during acute infections. Here we address the role of DJ-1 in bacterial sepsis. Some of the results of these studies have been previously reported as abstracts (35-37).

\section{Methods}

\section{Plasma and Polymorphonuclear Cells from Patients with Sepsis}

The Ethics Committee at McMaster University and St. Michael's Hospital approved all study protocols. Study criteria and patient selection have been published (38). Written informed consent was obtained from all enrolled patients or substitute decision makers and from consenting adult healthy volunteers. Neutrophil isolation is described in the online supplement (39).

\section{Animals}

Protocols were approved by the Animal Care Committee at St. Michael's Hospital. Wild-type (WT) C57Bl/6J (Jackson Laboratories, Bar Harbor, ME) and DJ-1-deficient mice (targeted deletion of DJ-1 [DJ-1 $\left.\left.{ }^{-/-}\right][40]\right)$ on a C57Bl/6J background (20 backcrosses).

\section{Cecal Ligation and Puncture Model}

Male mice (25-30 g) were randomized to cecal ligation and perforation (CLP) or sham surgery (see the online supplement) $(9,41,42)$.

\section{Plasma/Serum DJ-1 Levels}

DJ-1 levels in human plasma and mouse serum were determined by ELISA (Cusabio Biotech Co., Ltd., Wuhan, China), according to manufacturer's instructions.

\section{Serum Biochemistry Analyses and Measurement of Levels of Inflammatory Mediators}

VetScan Comprehensive Diagnostic Profile (VetScan Test Panels, University Health Network, Toronto, Ontario, Canada) was used to perform serum biochemistry analysis. Inflammatory mediators were measured using Procarta Cytometric Bead Array (Affymetrix Panomics, Santa Clara, CA), according to manufacturer's instructions (see online supplement).

\section{Isolation of Bone Marrow-derived Macrophages}

Bone marrow-derived macrophages

(BMMs) were isolated as described (43). 


\section{ROS Measurements}

Cellular and mitochondrial ROS in BMMs were assessed by CM-H2DCFDA and MitoSOX (see online supplement).

Dihydrochlorofluorescein fluorescence was measured in lung and spleens lysates using the OxiSelect ROS/RNS assay kit (Cell Biolabs, Inc., San Diego, CA), according to manufacturer's instructions. Values were normalized to protein input.

\section{Respiratory Burst in Polymorphonuclear Cells}

Burst measurement in septic polymorphonuclear cells (PMNs) is described in the online supplement (44).
Assessment of Cellular Bioenergetics, Phagocytosis, and Bacterial Killing

See the online supplement for further details.

\section{Loss and Gain of Function}

BMMs or THP-1 cells were transfected with mouse or human siRNA against DJ-1 (DJ-1 siRNA, loss of function), or a control
A

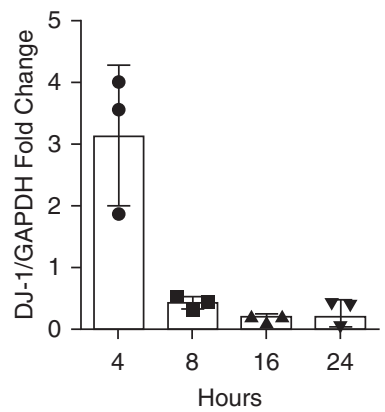

B

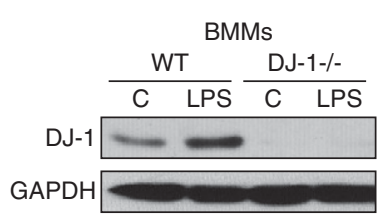

D

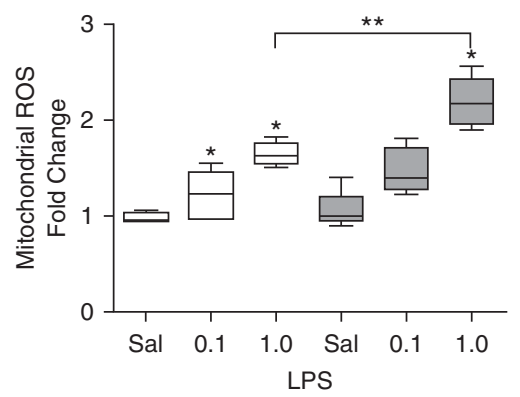

E

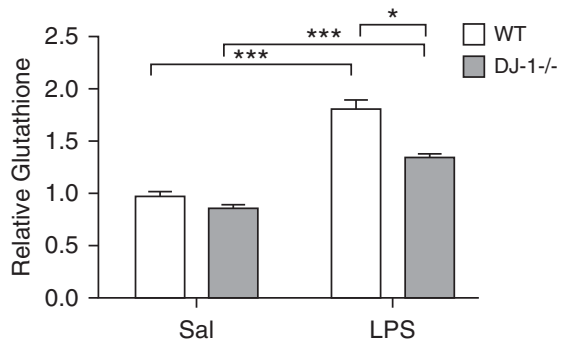

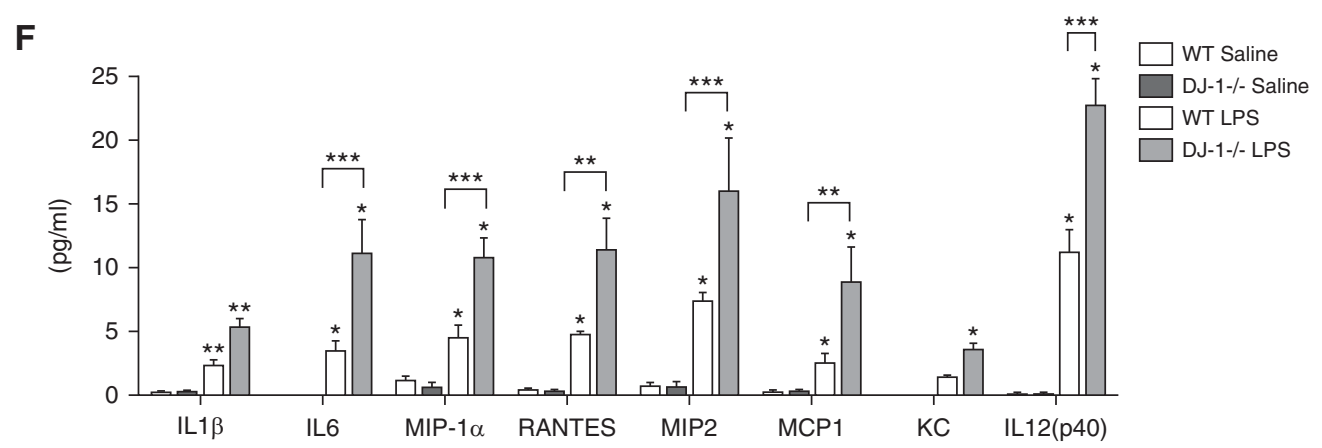

Figure 1. DJ-1 reduces inflammation and reactive oxygen species (ROS) production in bone marrow-derived macrophages (BMMs) after endotoxin challenge. (A) Real-time polymerase chain reaction results for changes in the expression of DJ-1 messenger RNA (mRNA) in BMMs exposed to saline or LPS $(1 \mu \mathrm{g} / \mathrm{ml})$ over 24 hours. Bar graphs represent fold change of DJ-1 expression over the saline control at each time point normalized to glyceraldehyde dehydrogenase (GAPDH) expression. (B) Representative Western blot and quantification $(n=5)$ showing increased DJ-1 protein expression in BMMs from wild-type $(\mathrm{WT})$ compared with DJ-1 ${ }^{-1-}$ mice after 24 hours of LPS stimulation $(1 \mu \mathrm{g} / \mathrm{ml})$ normalized to GAPDH protein expression. Bar graphs represent means \pm SEM $\left({ }^{*} P \leqslant 0.05\right.$, Student's $t$ test). $(C)$ Intracellular and (D) mitochondrial ROS in WT and DJ-1 ${ }^{-1-}$ BMMs after saline and increasing doses of LPS (0.1-1 $\left.\mu \mathrm{g} / \mathrm{ml}\right)$. (E) Relative total glutathione content in WT and DJ- $1^{-1-}$ BMMs after 24-hour exposure to saline or LPS $(1 \mu \mathrm{g} / \mathrm{mll})$. Bar graphs represent means \pm SEM ( ${ }^{*} P \leqslant 0.05$; ${ }^{* \star} P \leqslant 0.001$; two-way analysis of variance). (F) Levels of inflammatory mediators in LPS-treated BMMs cell lysate from WT versus DJ- $1^{-1-}$ mice. BMMs were treated with or without LPS (1 $\left.\mu \mathrm{g} / \mathrm{ml}\right)$ for $24 \mathrm{hours,}$ and inflammatory mediator response was determined using multiplex ELSA. Mediators profiled: IL-1 $\beta$, IL-6, IL-12 (p40), macrophage inflammatory protein (MIP)- $1 \alpha$, RANTES (CCL5), MIP-2, KC (chemokine [C-X-C motif] ligand 1), and monocyte chemoattractant protein-1 (MCP-1/CCL2). Bar graphs represent means \pm SEM $\left(\mathrm{n}=3\right.$; ${ }^{\star} P \leqslant 0.05 ;{ }^{\star} P \leqslant 0.01$, two-way analysis of variance). $\mathrm{C}=$ control; RANTES = regulated upon activation, normal $\mathrm{T}$ cell expressed and secreted; Sal $=$ saline. 
A

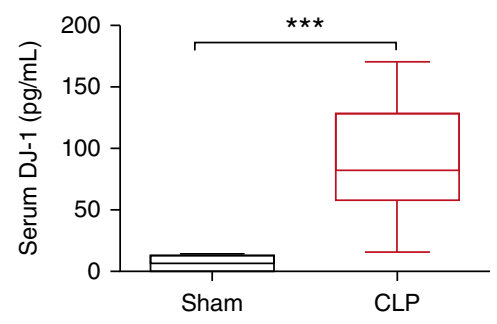

B

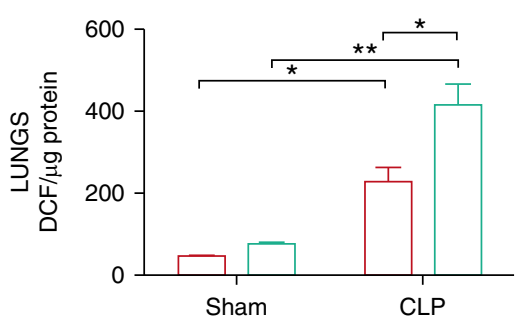

D

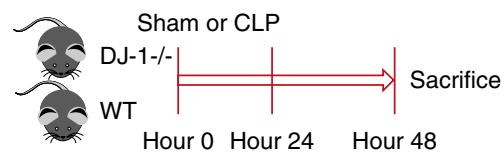

C

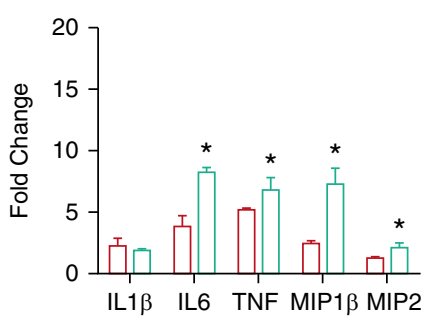

Serum $48 \mathrm{hrs}$

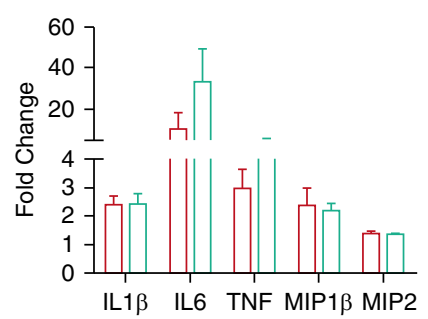

Lung 24 hrs

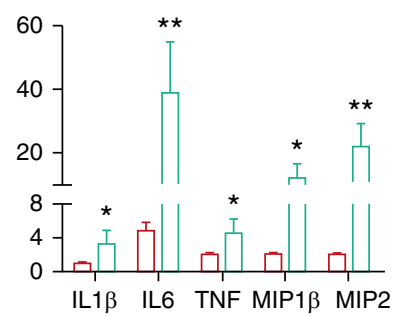

Lung 48 hrs

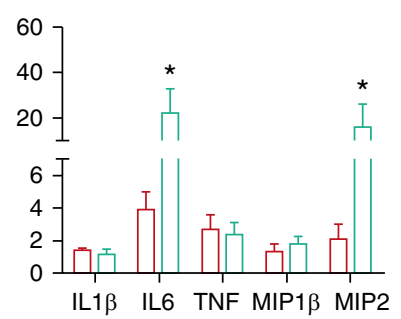

E
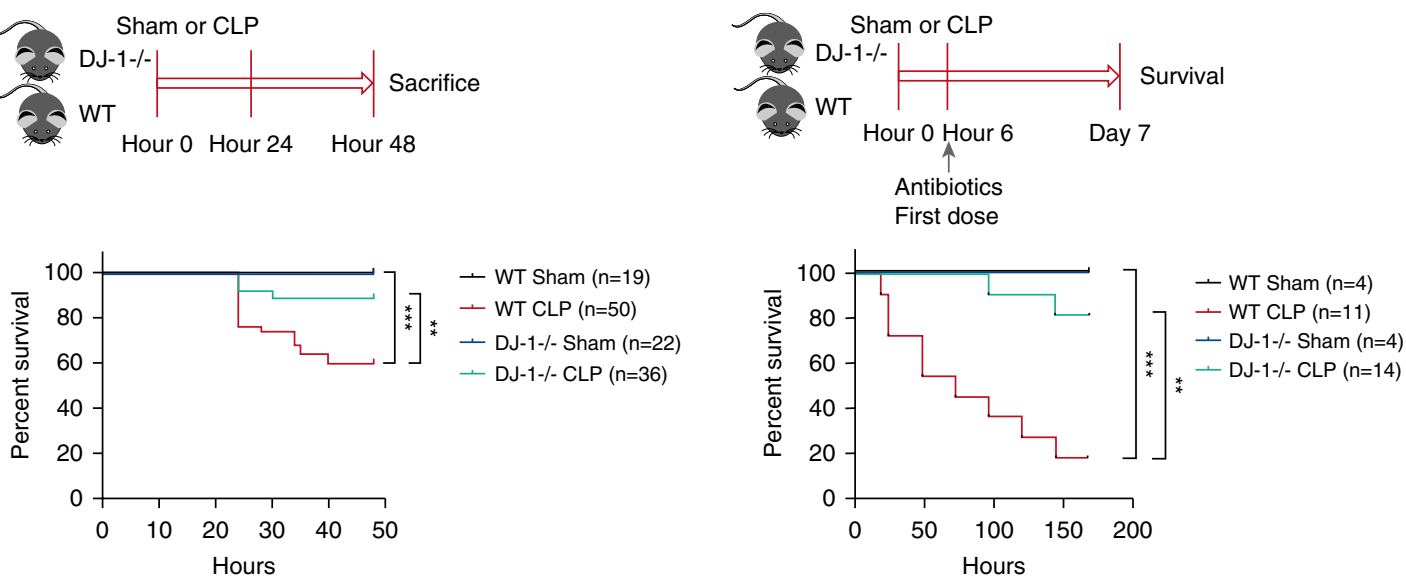

$\mathbf{F}$
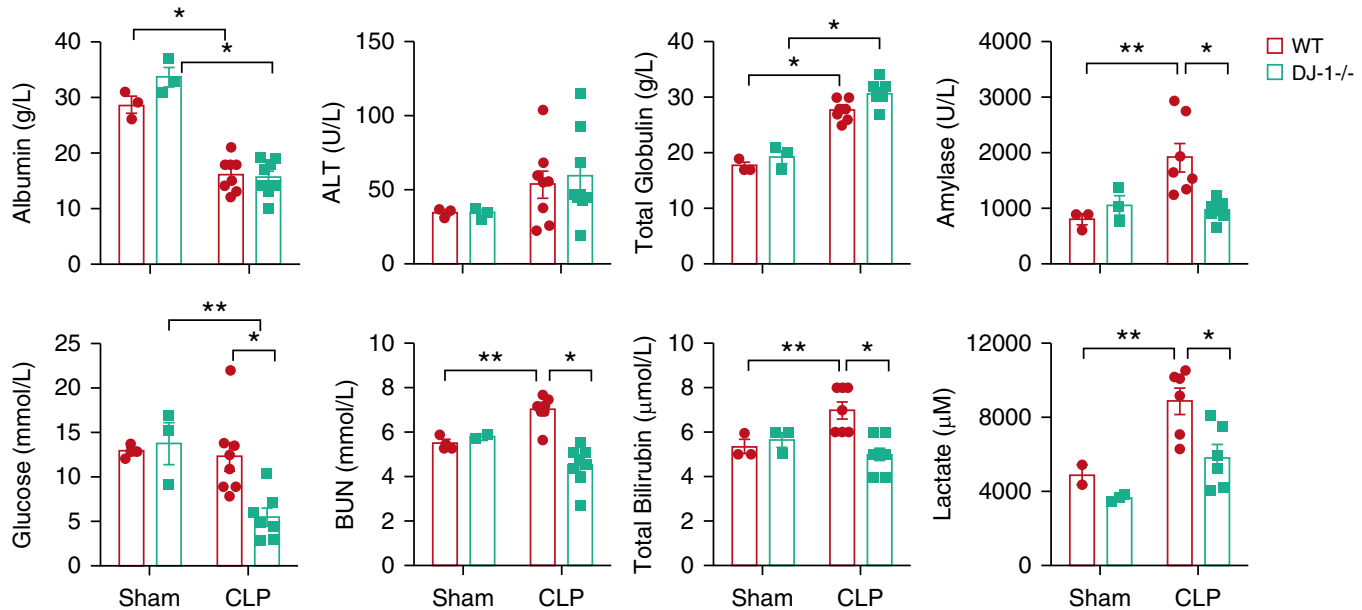

Figure 2. DJ-1 deficiency increases inflammation but improves survival and organ function after cecal ligation and perforation (CLP). (A) Serum levels of DJ-1 protein $(\mathrm{pg} / \mathrm{ml})$ in mice 24 hours after sham or CLP surgery. Data are presented as means \pm SEM $\left(n=8-10\right.$ per group; ${ }^{* \star *} P \leqslant 0.001$; Student's $t$ test). (B) Levels of reactive oxygen species in lung homogenates from wild-type (WT) and DJ- $1^{-1-}$ mice 24 hours after CLP, presented as dihydrochlorofluorescein (DCF) levels per microgram of protein. Data are presented as means \pm SEM $\left(n=6-8\right.$ per group; ${ }^{*} P \leqslant 0.05 ;{ }^{* *} P \leqslant 0.01$; two-way 
scrambled siRNA (ctrl siRNA; Ambion, Foster City, CA). Alternatively, BMMs were infected (50 multiplicity of infection) overnight with recombinant adenovirus overexpressing DJ-1 (Ad-DJ-1, gain of function) or a control adenovirus (Ad-Ctrl) (see online supplement).

\section{Statistical Analyses}

Mice were randomized (random number generator) to treatment groups, investigators blinded to genotype, and evaluators blinded to group assignment. Survival studies were analyzed using logrank (Mantel-Cox) tests. Based on sample size calculation eight animals per group would allow us to detect a significant difference in 7 -day mortality with $95 \%$ confidence. Unless otherwise stated, data are presented as mean \pm SEM. Differences between groups were determined using Mann-Whitney, Student's $t$ test, one-way analysis of variance, or two-way analysis of variance followed by Bonferroni post hoc test to account for both "genotype" and "treatment."

\section{Results}

\section{DJ-1 Reduces ROS Production and Inflammation in BMMs after Endotoxin Challenge}

BMMs were isolated from WT and DJ-1 $1^{-1-}$ mice. DJ-1 mRNA and protein expression were up-regulated in WT BMMs in response to LPS $(1 \mu \mathrm{g} / \mathrm{ml})$ (Figures $1 \mathrm{~A}$ and $1 \mathrm{~B})$. Levels of cellular ROS and mitochondrial ROS were comparable between genotypes at baseline. After stimulation, both cellular and mitochondrial ROS increased in DJ-1 $1^{-/-}$ BMMs compared with WTs (Figures $1 \mathrm{C}$ and 1D). Proinflammatory mediator levels were also higher in DJ-1 $1^{-/}$BMM (Figure 1F). In addition, we have previously shown DJ-1 deficiency results in Nrf2 (nuclear factor, erythroid 2-like 2) degradation $(16,43)$. Consistent with a decrease in Nrf2 transcriptional activity, glutathione, heme oxygenase 1, glutathione peroxidase 1 (Gpx-1), and manganese superoxide dismutase expression was not increased in DJ-1 $1^{-1-}$ BMMs (Figure 1E; see Figure E1A). DJ-1 deficiency in BMMs had no effect on cellular viability (see Figure E1B).

\section{DJ-1 Deficiency Increases ROS Production and Inflammation after CLP}

We randomized WT and DJ-1 ${ }^{-1-}$ mice to a fluid resuscitated model of CLP-induced polymicrobial sepsis versus sham surgery. Elevated circulating DJ-1 levels were present in WT septic mice 24 hours after CLP (Figure 2A). ROS levels in lung lysates were higher in $\mathrm{DJ}-1^{-/-}$mice (Figure $2 \mathrm{~B}$ ). In the absence of DJ-1, circulating and pulmonary levels of proinflammatory mediators IL-1 $\beta$, IL-6, tumor necrosis factor (TNF), and macrophage inflammatory protein (MIP)-1 $\beta$ and MIP-2 increased at 24 and 48 hours (except for TNF and MIP-1 $\beta$ in lungs) (Figure 2C). Increased pulmonary mediator levels were associated with enhanced cellular recruitment into the alveolar space by 48 hours (see Figure E2C). CLP resulted in a twofold to threefold increase in bronchoalveolar fluid total protein and IgM levels in DJ-1 $1^{-1-}$ and WT mice at 24 hours (see Figure E2C), and this was sustained in $\mathrm{DJ}-1^{-9}$ mice at 48 hours.

\section{DJ-1-Deficient Mice Had Improved Survival and Organ Function in Response to CLP}

Despite evidence of increased ROS production and inflammation, DJ-1 deficiency significantly attenuated 7-day mortality in fluid-resuscitated, antibiotictreated CLP mice ( 81.82 vs. $18.18 \% ; P=0.0005$ )
(Figure 2E). Although WT mice became lethargic, stopped grooming, and showed moderate distress after CLP, DJ-1 ${ }^{-1-}$ mice showed no or only mild distress. Body weight and temperature were not significantly different between genotypes (see Figure E2A). Resistance to CLP-induced mortality was observed in DJ-1 ${ }^{-1-}$ mice even in the absence of antibiotics (60 vs. $88.8 \%$ survival; $P=0.006$ ) (Figure $2 \mathrm{D}$ ) and irrespective of perforation size (see Figure E2B).

Assessment of serum biochemical markers of organ dysfunction determined lactate levels, although increased in both CLP groups at 24 hours after CLP, were significantly lower in $\mathrm{DJ}-1^{-/-}$mice (Figure 2F). Albumin levels were decreased, whereas alanine amino transferase was increased equally in both genotypes. Total bilirubin, blood urea nitrogen, amylase, and glucose levels were lower in the DJ-1 $1^{-/-}$ mice (Figure 2F).

\section{DJ-1 Impairs Bacterial Clearance and M1 Polarization of Professional Phagocytes}

A potential explanation for improved survival is enhanced source control. DJ- $1^{-/-}$ mice had significantly lower bacterial counts in blood, lung, and spleen (12 and $24 \mathrm{~h}$ after CLP) (Figure 3A). Because M1 macrophages may enhance bacterial clearance, we isolated peritoneal cells from WT and DJ-1 ${ }^{-1-}$ mice 12 hours after CLP. In addition to enhanced expression of proinflammatory cytokines, absence of DJ-1 resulted in an increase in the proportion of CD80 (cell surface marker for M1 phenotype) and inducible nitric oxide synthase (iNOS) mRNA expression. In parallel, $\mathrm{CD}_{206}{ }^{+}$(marker for M2 phenotype) (Figure 3B) cells, and YM1 expression was significantly decreased, and a trend toward lower arginase 1 mRNA expression (Figure $3 \mathrm{C}$ ). iNOS protein was

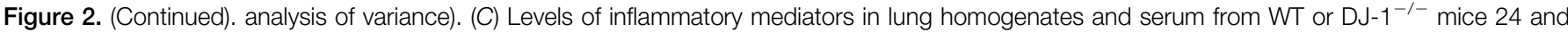

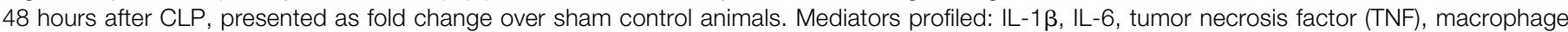

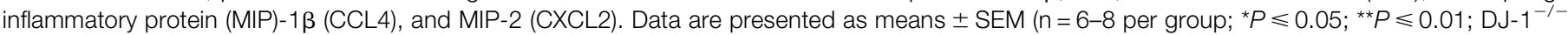

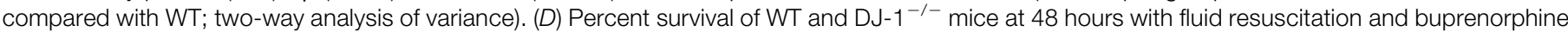

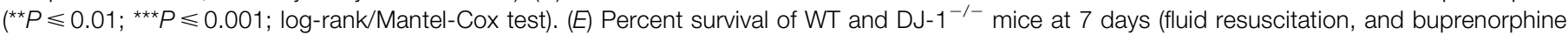

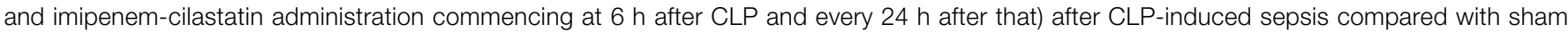

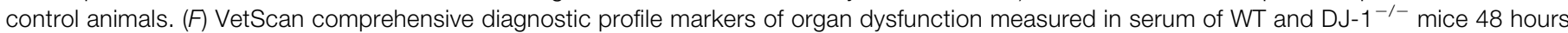

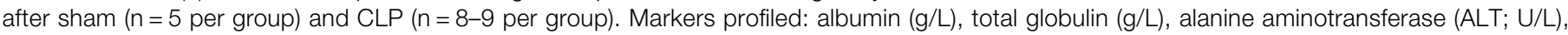
total bilirubin ( $\mu \mathrm{mol} / \mathrm{L})$, blood urea nitrogen (BUN; mmol/L), amylase (U/L), and glucose (mmol/L). Serum lactate levels ( $\mu \mathrm{M})$ was measured at

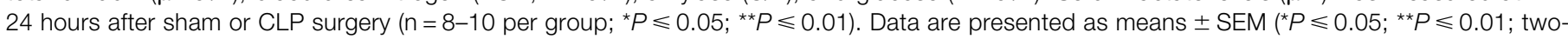
way analysis of variance). 
A
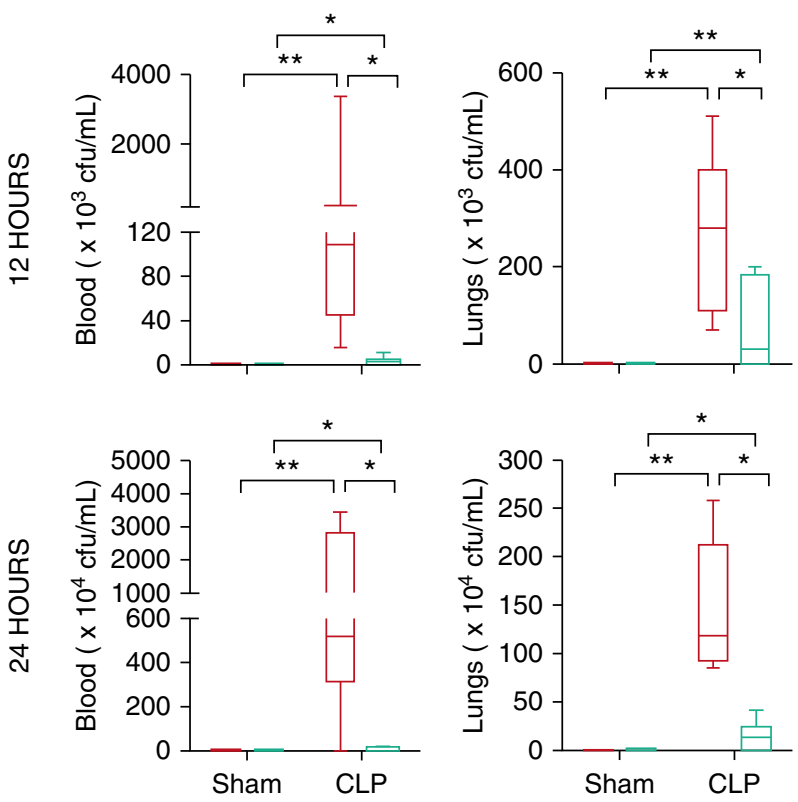
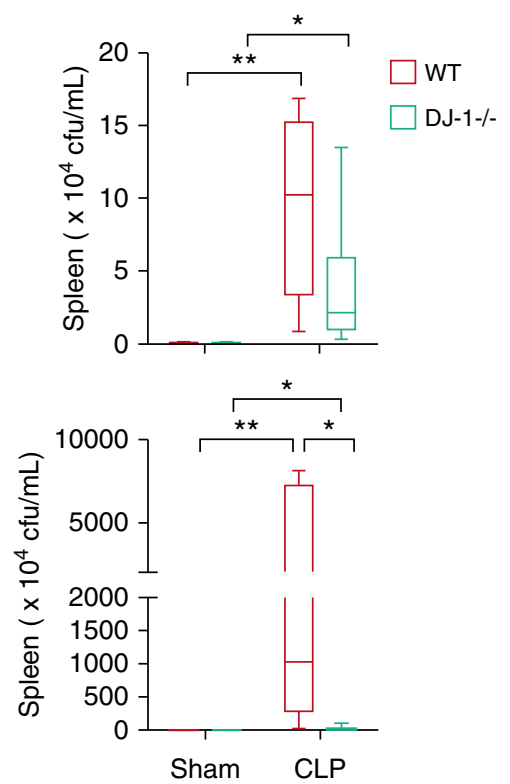

B

\section{PERITONEAL CELLS}

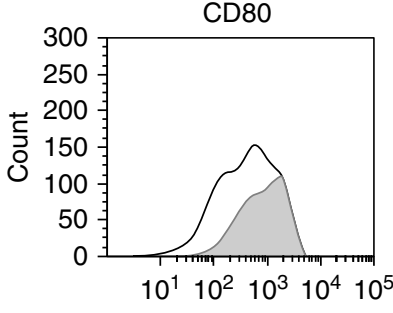

PE-A

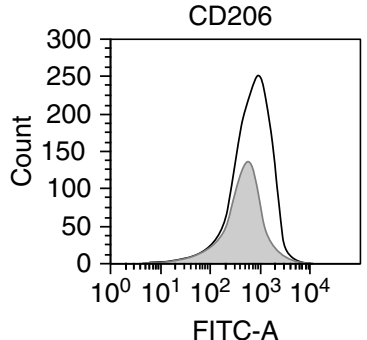

FITC-A
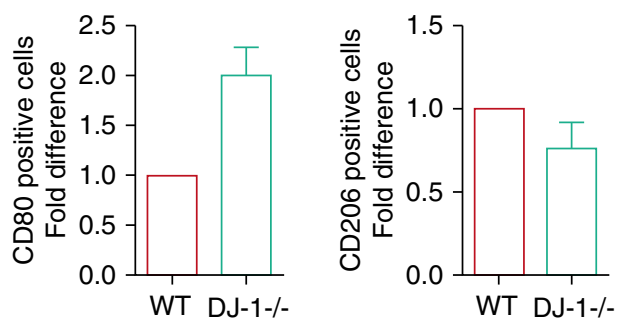

C
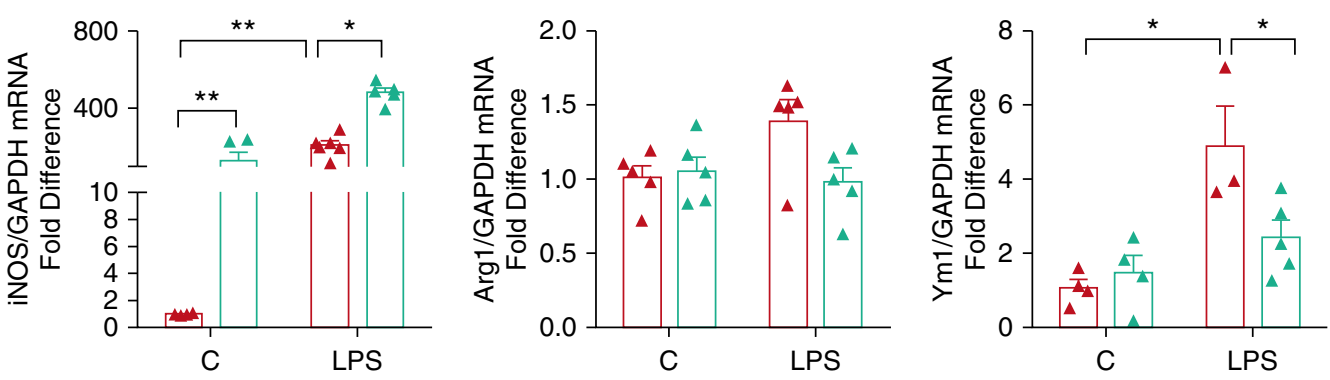

D

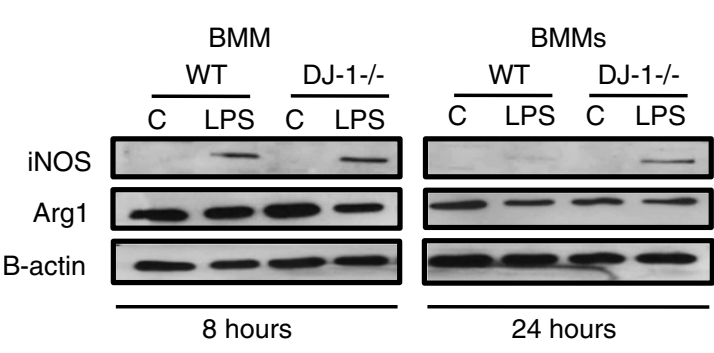

E

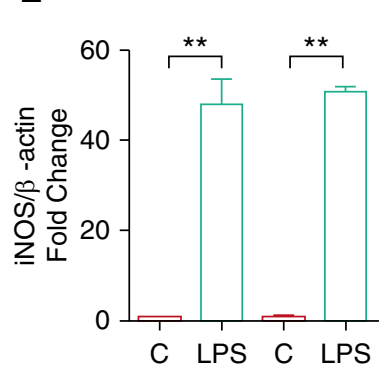

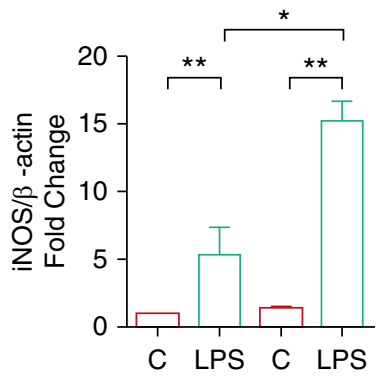

Figure 3. DJ-1 impairs bacterial clearance and M1 polarization of professional phagocytes. (A) Bacterial load, represented as cfu/ml, in blood, lungs, and spleen 12 and 24 hours after cecal ligation and perforation (CLP) surgery. In the box-and-whisker plots, the median is indicated with a horizontal line in the interior of the box, and the maximum and minimum are at the ends of the whiskers $\left(n=5-8\right.$ per group; ${ }^{\star} P \leqslant 0.05 ;{ }^{\star \star} P \leqslant 0.01$; two-way analysis of 
increased in WT and DJ-1 $1^{-/-}$BMMs (Figures $3 \mathrm{D}$ and $3 \mathrm{E}$ ), whereas arginase 1 protein levels were decreased. iNOS expression was increased in DJ-1 ${ }^{-/-}$lungs and spleens 24 hours after CLP surgery (see Figures E3A and E3B).

\section{DJ-1 Impairs Bacterial Killing}

Improved bacterial clearance in vivo was associated with enhanced phagocytosis by $\mathrm{DJ}-1^{-/-}$peritoneal cells in vitro. We incubated WT and DJ-1 ${ }^{-1-}$ peritoneal cells isolated 12 hours after CLP (Figure 4A; see Figure E4A) or after thioglycollate stimulation (see Figure E4B) with fluorescent Escherichia coli bioparticles. Phagocytosis of E. coli bioparticles also increased in DJ-1 ${ }^{-1-}$ compared with WT BMMs and this effect was sustained over time (Figure 4B). Compared with WT $\mathrm{BMMs}$, increased pHrodo ( $\mathrm{pH}$ sensitive dye) labeled E. coli and Staphylococcus aureus was also observed in DJ-1 $1^{-/-}$ BMMs at baseline (nonstimulated) and after 1-hour prestimulation with LPS (Figure 4C), consistent with acidification of the phagolysosomal compartment. Inhibition of ROS generation with Bay-11 7082 (an inhibitor of nuclear factor of kappa light polypeptide gene enhancer in B-cells inhibitor, alpha [ІКB- $\alpha]$ ) or mitoTEMPO (a mitochondria-targeted superoxide dismutase mimetic), attenuated the enhanced phagocytic phenotype in DJ-1 ${ }^{-1-}$ BMMs (see Figures E5A and E5B).

To determine bactericidal activity, we infected WT and DJ-1 $1^{-/-}$BMMs with E. coli or S. aureus for 30 or 60 minutes and treated with gentamicin. Bacteria that are not engulfed (remain extracellular) are killed by the antibiotic. After cell lysis, the resulting bacterial colonies represent intracellular viable bacteria that phagocytes have failed to kill. DJ-1 ${ }^{-/-}$BMMs had significantly decreased number of viable bacterial colonies 30 and 60 minutes postinfection compared with WT BMMs (Figure 4D).

\section{Adoptive Transfer of DJ-1-Deficient Bone Marrow-derived Mononuclear Cells Improved Survival in WT Mice after CLP Surgery}

To demonstrate that DJ-1-deficient phagocytes are more effective in eliminating bacteria early in the course of sepsis, conferring a beneficial survival effect, we isolated bone marrow-derived mononuclear cells (BMCs) from WT and DJ-1 $1^{-/-}$mice and administered to WT mice 6 hours after the induction of CLP (Figure 5A). Treatment with DJ-1 ${ }^{-/-}$ BMCs significantly improved 7-day survival after CLP surgery compared with WT BMCs and saline controls (Figure 5B).

\section{DJ-1 Reduces Mitochondrial ROS Production}

It is unknown whether loss of DJ-1 affects mitochondrial respiration in professional phagocytes but ineffective mitochondrial respiration generates ROS. Accordingly, we measured mitochondrial respiration and uncoupling in WT and DJ-1 ${ }^{-1-}$ BMMs. DJ-1 partially localized to mitochondria in unstimulated and LPS-stimulated BMMs (Figure 5C). Basal oxygen consumption rate, a measure of mitochondrial respiration, was not significantly different between DJ-1 ${ }^{-1-}$ and WT BMMs.

Exposure to TNF, however (6 h), unmasked a significant decrease in oxygen consumption rate in $\mathrm{DJ}-1^{-/-} \mathrm{BMMs}$ (Figures 5D and 5E). No difference was noted after 24 hours of treatment (data not shown). Although there was a modest increase in proton leak in DJ-1 $1^{-1-}$ BMMs at baseline, there was no significant difference after treatment (Figure 5F). Furthermore, addition of carbonyl cyanide4-(trifluoromethoxy) phenylhydrazone, which uncouples proton pumping from ATP synthesis, maximized oxygen consumption rate in WTs while DJ-1 ${ }^{-/-}$ BMMs remained unresponsive (Figures $5 \mathrm{~F}$ and 5G). Therefore, although 6 hours of TNF treatment had profound effects on cellular metabolic pathways (decreased basal and maximal respiration) in DJ-1 ${ }^{-1-}$ cells compared with WT cells, ROS emission increased normally in $\mathrm{DJ}-1^{-1-}$ cells in response to a longer exposure to TNF (24 h) suggesting another mechanism may explain increased ROS after proinflammatory stimulation.

\section{DJ-1 Reduces NADPH Oxidase-Dependent ROS Generation} ROS generation by the NADPH oxidase complex is critical in host defense. The NADPH oxidase is a multisubunit complex consisting of two membrane proteins, $\mathrm{p} 22^{\mathrm{phox}}$ and the catalytic subunit, Nox2 (gp91 ${ }^{\text {phox }}$ ), and the cytosolic proteins, $\mathrm{p} 47^{\text {phox }}, \mathrm{p} 67^{\text {phox }}$, $\mathrm{p} 40^{\text {phox }}$, and Rac- 1 . We first assessed whether DJ-1 deficiency resulted in regulation of the subunits of the NOX complex. Expression of Nox2 (gp91 ${ }^{\text {phox }}$ ) mRNA (Figure 6A) and Nox2 and $\mathrm{p} 47^{\text {phox }}$ protein were increased in DJ-1 $1^{-/-}$ versus WT BMMs at baseline and in response to LPS (Figure 6B). In parallel, knockdown of DJ-1 expression (see Figure E6A) in WT BMMs resulted in increased Nox 2 and $\mathrm{p} 47^{\text {phox }}$ protein expression after LPS stimulation (Figure 6B). Conversely, overexpression of DJ-1 (see Figure E6A) attenuated Nox2 and $\mathrm{p} 47^{\text {phox }}$ expression (Figure $6 \mathrm{C}$ ).

NADPH oxidase activity (see Figure E7A) was also increased in DJ-1 ${ }^{-/-}$BMMs. Treatment with diphenyleneiodonium, an inhibitor of NADPH oxidase, normalized ROS burst in WT and DJ-1 $1^{-/-}$ BMMs (see Figure E7B). Phosphorylation of $\mathrm{p} 47^{\text {phox }}$ mediates interaction of the various NADPH complex and Nox2 activation (45). Phosphorylation of $\mathrm{p} 47^{\text {phox }}$ is enhanced in DJ-1 ${ }^{-1-}$ BMMs after stimulation with LPS or live E. coli bacteria (EB) (Figure 6D). This was replicated in WT BMMs treated with DJ-1 siRNA (see Figure E7C).

Figure 3. (Continued). variance). (B) Flow cytometric analysis and bar graph of activation surface markers on M1 and M2 macrophage subsets. F4/80positive wild-type (WT) (black) and DJ-1 ${ }^{-1-}$ (gray) peritoneal cells were assessed for CD80 and CD206 receptor expression. (C) Real-time polymerase chain reaction results for changes in the expression of mRNA for inducible nitric oxide synthase (iNOS), arginase 1 (Arg1), and Ym1 normalized to glyceraldehyde 3-phosphate dehydrogenase (GAPDH) in WT and DJ-1 ${ }^{-1-}$ bone marrow-derived macrophages (BMMs) 24 hours after LPS. Data are presented as means \pm SEM $\left(n=3\right.$ per group; ${ }^{\star} P \leqslant 0.05$; ${ }^{\star \star} P \leqslant 0.01$; two-way analysis of variance). (D) Representative Western blot showing iNOS and Arg1 protein expression in WT and DJ-1 $1^{-1-}$ BMMs after 8 and 24 hours of LPS treatment. Gels are normalized to $\beta$-actin expression. ( $E$ ) Densitometry analysis showing quantification of iNOS protein expression at 8 and 24 hours. Data are presented as means \pm SEM $\left(n=3\right.$ per group; ${ }^{\star} P \leqslant 0.05$; ${ }^{\star \star} \mathrm{P} \leqslant 0.01$; two-way analysis of variance). $\mathrm{C}=$ control; $\mathrm{cfu}=$ colony-forming unit; FITC-A = fluorescein isothiocyanate-A; $\mathrm{PE}-\mathrm{A}=\mathrm{phycoerythrin-A}$. 
A

AlexaFluor 488
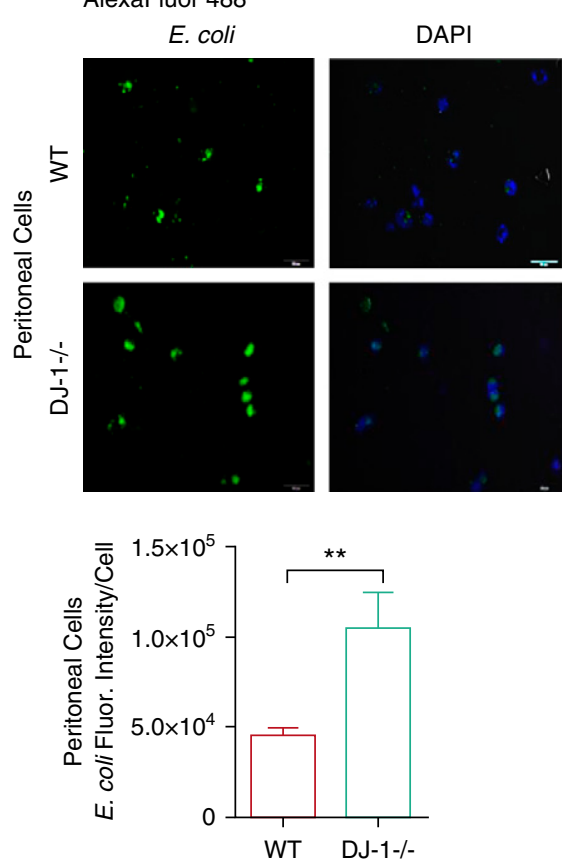

B

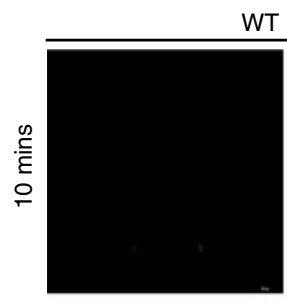

WT BMM
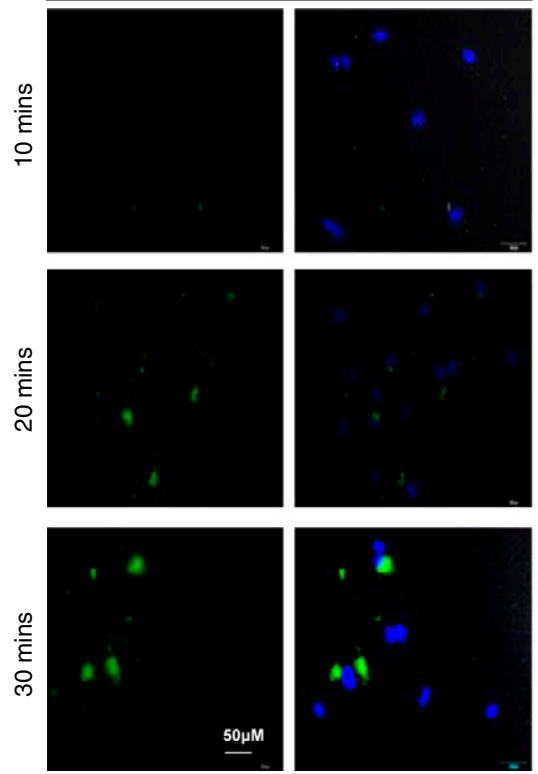

DJ-1-/- BMM
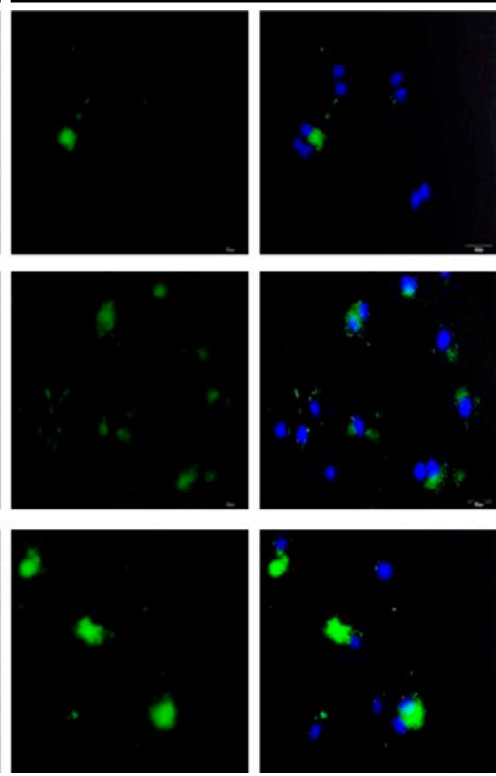

C
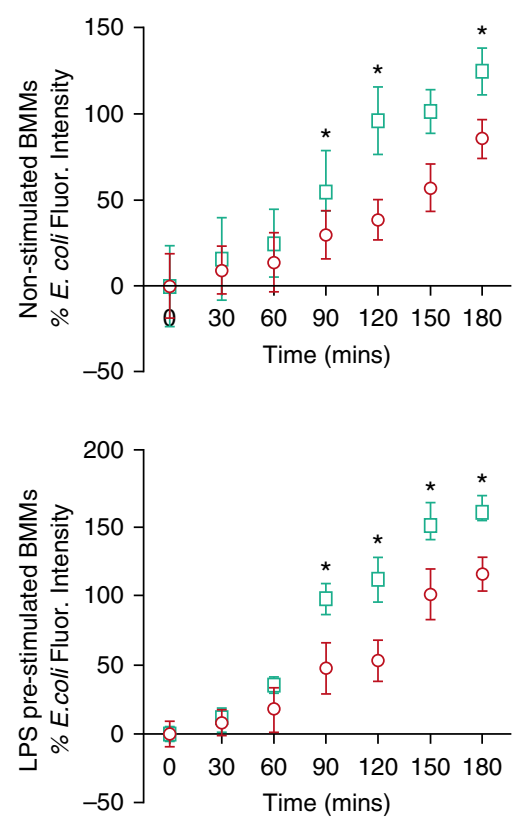

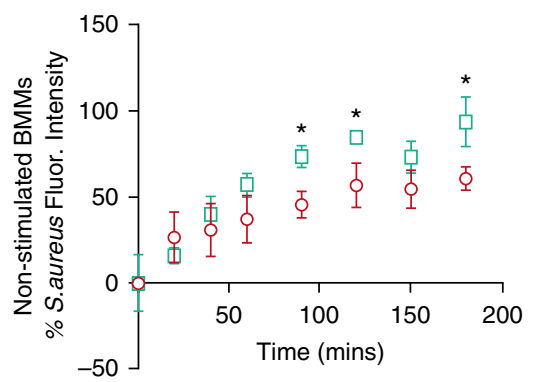

D
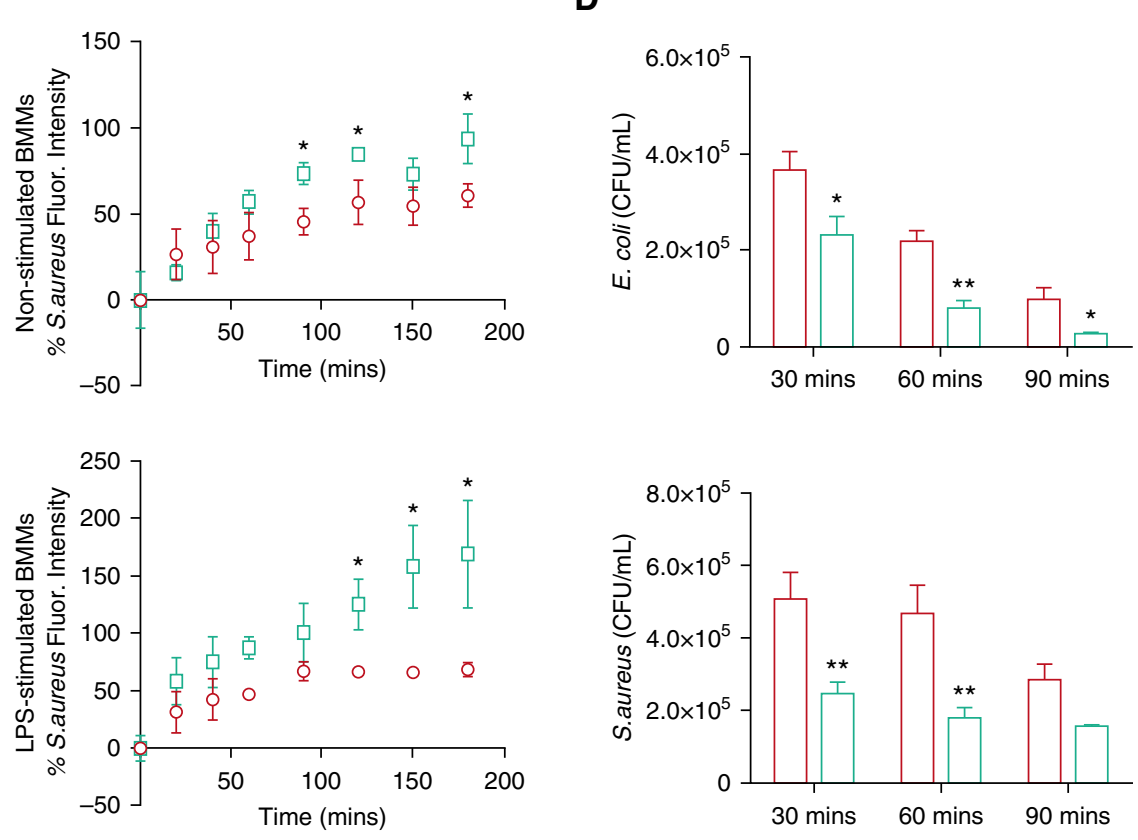

Figure 4. Effect of DJ-1 deficiency on bacterial clearance and phagocytosis. (A, top) Representative images of wild-type (WT) and DJ-1 ${ }^{-/-}$peritoneal cells isolated after 12 hours of cecal ligation and perforation surgery and incubated with Alexa Fluor 488-conjugated Escherichia coli (K-12 strain) BioParticles (Life Technologies) for 30 minutes (captured at $\times 100)$. (A, bottom) Quantified phagocytosis of Alexa Fluor 488-conjugated E. coli in WT and DJ-1 ${ }^{-/-}$ peritoneal cells, represented as means \pm SEM $\left({ }^{\star \star} P \leqslant 0.01\right)$ of fluorescence intensity per cell from 10 representative images. Scale bars: $20 \mu m$.

(B) Representative fluorescence images of WT and DJ-1 ${ }^{-/-}$bone marrow-derived macrophages (BMMs) with green pHrodo $E$. coli bioparticles and blue (DAPI) nuclear staining over a course of 30 minutes. (C) Measurement of phagocytic function of WT and DJ- $1^{-/-}$BMMs using E. coli or Staphylococcus aureus pHrodo Bioparticles with no stimulation and 1 hour prestimulation with LPS (1 $\mu \mathrm{g} / \mathrm{ml})$. Assays were conducted in 96-well plates in triplicate and repeated twice. Data were normalized to baseline values at time 0 and presented as \% fluorescence intensity. The fluorescence intensity was read using SpectraMax plate reader. Results are presented as means \pm SEM $\left.{ }^{*} P \leqslant 0.05\right)$. $(D)$ Measurement of bacterial killing activity in WT and DJ-1 ${ }^{-1-}$ BMMs by gentamicin protection assay at 30, 60, or 90 minutes after $E$. coli or $S$. aureus infection. Data are presented as means \pm SEM $(n=5-6$ per group; ${ }^{\star} P \leqslant 0.05 ;{ }^{\star} P \leqslant 0.01$; two-way analysis of variance). CFU = colony-forming unit; DAPI = 4',6-diamidino-2-phenylindole; Fluor. = fluorescence. 
A

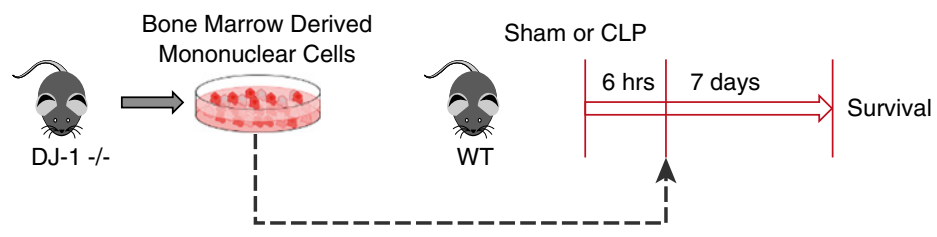

B

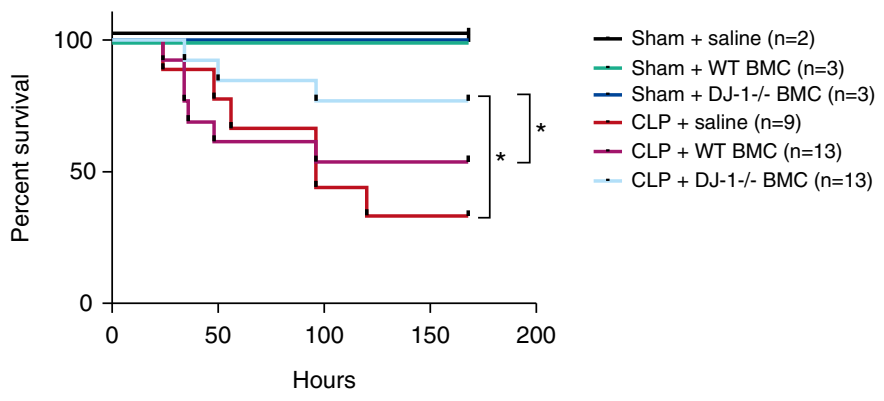

C
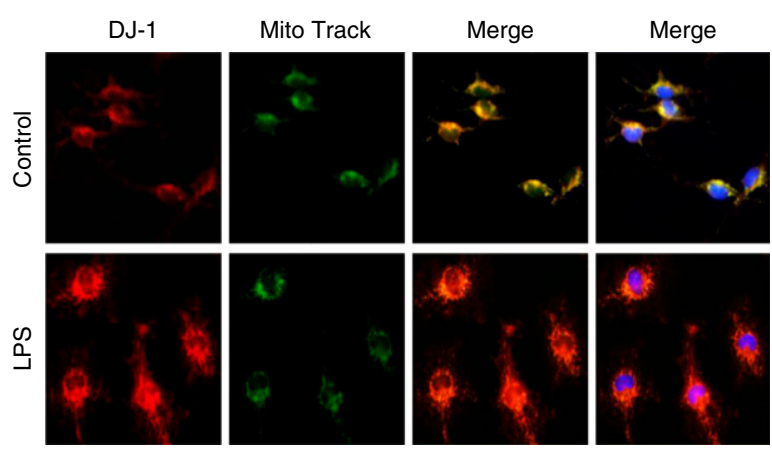

E

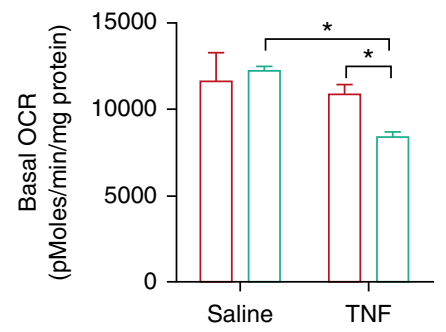

D

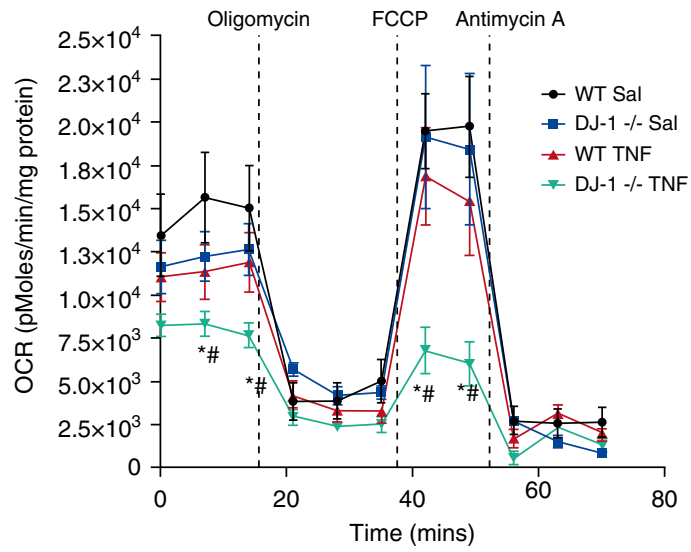

G

$\mathbf{F}$

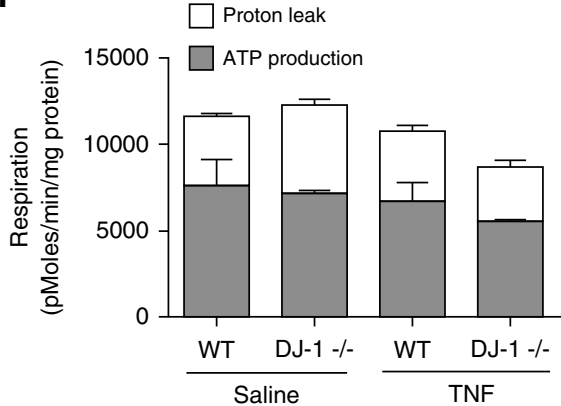

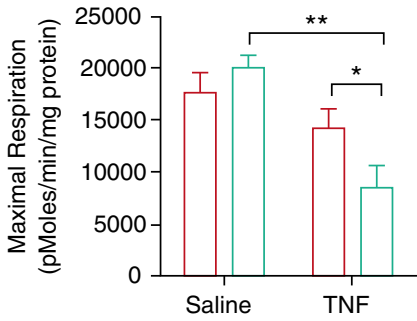

Figure 5. Adoptive transfer of bone marrow-derived mononuclear cells (BMCs) and role of DJ-1 in mitochondrial respiration. (A) Schematic of adoptive transfer of DJ-1-deficient BMCs in wild-type (WT) mice exposed to sham or cecal ligation and perforation (CLP) surgery. (B) Percent survival of WT mice at 7 days (fluid resuscitation, and buprenorphine and imipenem-cilastatin administration) after CLP-induced sepsis with administration of WT and DJ-1 ${ }^{-/-}$ BMCs 6 hours after sham or CLP surgery ( ${ }^{*} P \leqslant 0.05$; Student's $t$ test comparing CLP + WT BMCs vs. CLP $\left.=\mathrm{DJ}-1^{-1-} \mathrm{BMCs}\right)$. $(C)$ Representative fluorescent images of DJ-1 expression (red), mitochondria (green), merged (yellow), and with nuclear (b/ue) immunostaining at baseline and after 24 hours of LPS $(1 \mu \mathrm{g} / \mathrm{ml})$ treatment (captured on Olympus Upright Microscope at magnification of $\times 60)$. Assessment of cellular energetics and oxidative stress. (D) Representative oxygen consumption rate (OCR) curve in WT and DJ-1 $1^{-/-}$bone marrow-derived macrophages $\left(5 \times 10^{4}\right)$ after 6 hours of saline or tumor necrosis factor (TNF) treatment (10 ng/ml) using Seahorse Bioanalyzer with sequential treatment of oligomycin ( $1 \mu \mathrm{g} / \mathrm{ml})$, carbonyl cyanide 4-(trifluoromethoxy)phenylhydrazone (FCCP) $(1 \mu \mathrm{M})$, and antimycin A $(1 \mu \mathrm{M})$. Data are presented as means \pm SEM. ${ }^{*} P \leqslant 0.05$, analysis of variance compared with WT saline; ${ }^{\#} P \leqslant 0.05$, compared with WT TNF, analysis of variance. (E) Basal respiration rate, $(F)$ ATP production and proton leak, and $(G)$ maximal respiration calculated from three independent experiments. Data are presented as means \pm SEM $\left({ }^{\star} P \leqslant 0.05\right.$; ${ }^{\star \star} P \leqslant 0.01$; two-way analysis of variance). Sal $=$ saline. 
A

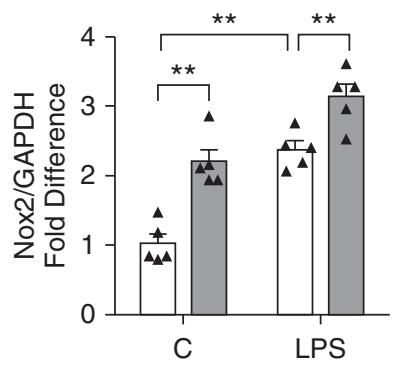

C

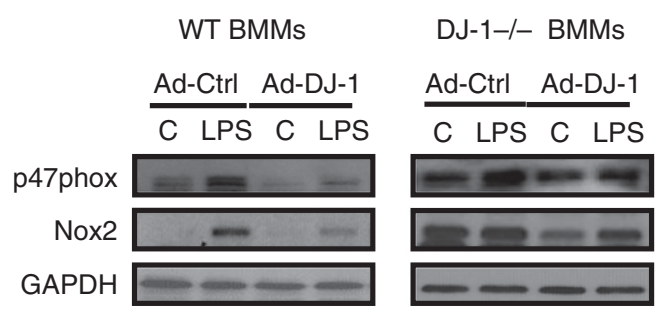

E

WT BMMs

$\frac{\text { Input }}{\text { C } \quad \text { LPS }} \frac{\stackrel{\text { IP }}{\text { DJ }-1}}{\text { C LPS }} \frac{\stackrel{I P}{\text { NC }}}{\text { LPS }}$

p47phox

p67phox

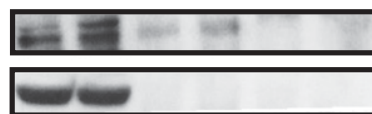

B

BMMs

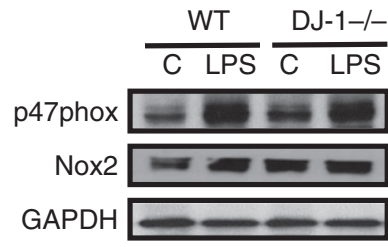

WT BMMs

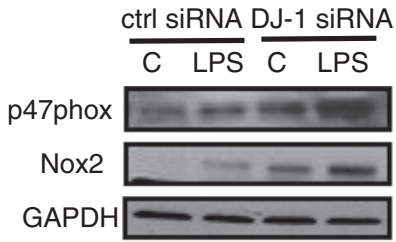

\section{D}

\begin{tabular}{|c|c|c|c|c|c|}
\hline & & VMs & & hMs & \\
\hline & WT & DJ-1-/- & WT & DJ-1-/- & \\
\hline & C LPS & $\overline{C \quad \text { LPS }}$ & $\overline{C E B}$ & $\overline{C E B}$ & \\
\hline phoserine & $+m$ & 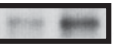 & -- & $=-$ & IP \\
\hline p47phox & -6 & $\Rightarrow$ & $=0$ & 80 & p47phox \\
\hline DJ-1 & $E-$ & & -- & & \\
\hline p47phox & $=$ & $=\equiv$ & $\square=$ & $=$ & Input \\
\hline GAPDH & $-\infty$ & $-\infty$ & $-\infty$ & -1 & \\
\hline
\end{tabular}

RAW 264.7

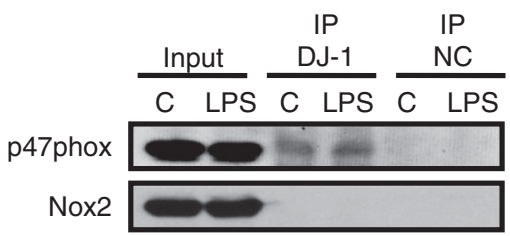

$\mathbf{F}$
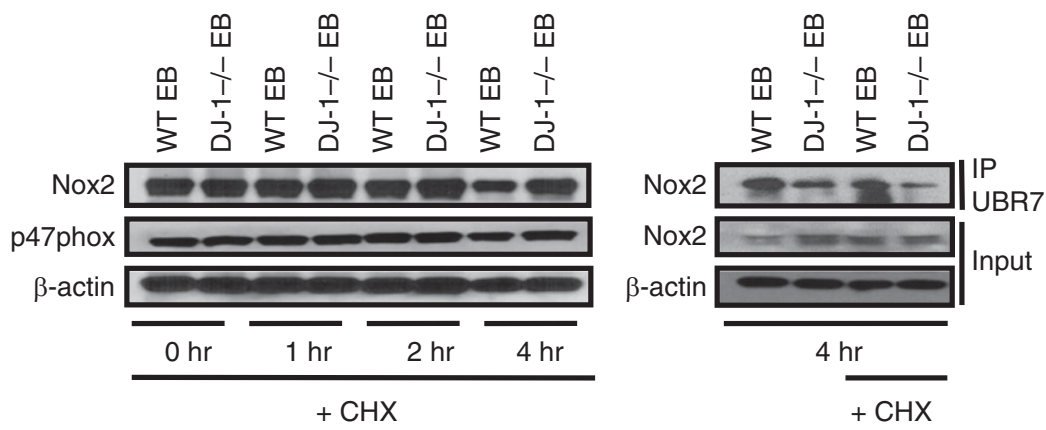

G

BMMs

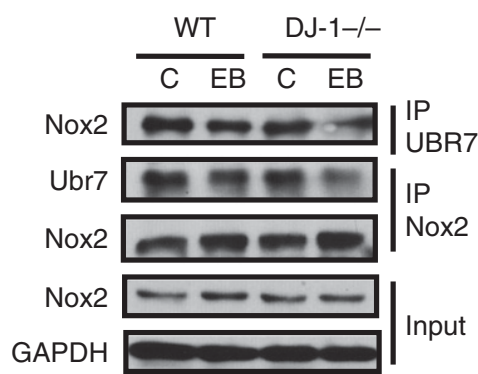

H

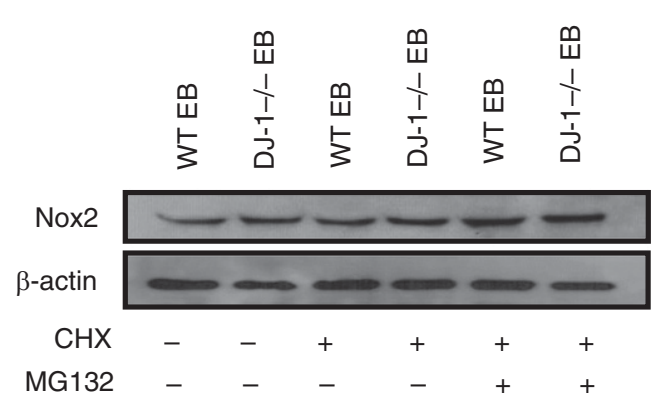

Figure 6. DJ-1 negatively regulates the NOX2 oxidase complex activity. (A) Real-time polymerase chain reaction results for changes in the expression of messenger RNA for Nox2 normalized to glyceraldehyde 3-phosphate dehydrogenase (GAPDH) in bone marrow-derived macrophages (BMMs) exposed to saline control (C) or LPS (1 $\mu \mathrm{g} / \mathrm{ml})$ over 24 hours. Data are presented as fold change over wild-type (WT) saline control with means \pm SEM 


\section{DJ-1 Binds to $\mathrm{p} 47^{\text {phox }}$ Disrupting NADPH Oxidase Complex and Promoting Nox2 Degradation}

We investigated if DJ-1 inhibits ROS production by binding to components of the NADPH oxidase. P $47^{\text {phox }}$ subunit coimmunoprecipitated with DJ-1 at baseline and after LPS stimulation in both BMM and RAW cells (Figure 6E) indicating DJ-1 binds to $\mathrm{p} 47^{\text {phox }}$. We did not observe binding of DJ-1 with the Nox 2 or $\mathrm{p} 67^{\text {phox }}$ subunits. We postulated binding of DJ-1 to $\mathrm{P} 47^{\text {phox }}$ could result in decreased ROS production because of loss of complex stability. After inhibition of de novo protein synthesis with cycloheximide, Nox 2 protein levels decreased over time in WT while remaining stable in DJ-1 BMMs exposed to E. coli bacteria (Figure 6F; see Figure E7D). Absence of DJ-1 reduced Nox2 ubiquitination after $E$. coli treatment (Figure 6G; see Figure E8E). The role of DJ-1 in complex disassembly was further supported by the evidence that cotreatment with the proteasome inhibitor, MG132, partially prevented decreased Nox2 protein expression in DJ-1 ${ }^{-/-}$BMMs (Figure $6 \mathrm{H}$ ).

\section{Absence of DJ-1 Also Protects from Pseudomonas aeruginosa Peritonitis} To address whether absence of DJ-1 was protective in other bacterial infection models, we administered Pseudomonas aeruginosa intraperitoneally to WT and $\mathrm{DJ}-1^{-/-}$mice. In line with our previous results, DJ-1 ${ }^{-1-}$ mice were resistant to Pseudomonas-induced mortality compared with WT mice (Figure 7A).

\section{DJ-1 Expression Modulates Bacterial Killing and Respiratory Burst in Human Phagocytes}

We further investigated the role of DJ-1 in human cells. DJ-1 protein expression was increased in THP-1 (human monocytic) cells exposed to LPS and in PMNs from patients with sepsis (Figures 7B, 7D, and 7E). Knockdown of DJ-1 in phorbol 12-myristate 13-acetate-activated THP-1 cells (see Figure E6B) resulted in increased E. coli or $S$. aureus bacterial killing (Figure 7C). Similarly, DJ-1 knockdown in PMNs from patients with sepsis $(n=5)$ modestly increased baseline respiratory burst in septic PMNs (Figure 7F). This increased after administration of phorbol 12-myristate 13-acetate, an activator of respiratory burst (Figure 7F).

Conversely, 1 hour pretreatment with diphenyleneiodonium, an NADPH oxidase inhibitor, abolished the enhanced respiratory burst in DJ-1 $1^{-1-}$ BMMs (Figure 7F). Silencing DJ-1 in PMNs (septic or healthy) did not significantly alter cell death (apoptosis; see Figure E6C).

\section{Circulating DJ-1 Levels Are Increased and Correlate with Markers of Sepsis Severity and Organ Dysfunction in Patients}

To determine if increased DJ-1 levels were also associated with poor outcomes in humans, we further identified elevated circulating levels of DJ-1 in patients with sepsis $(n=60)$ compared with healthy control subjects $(\mathrm{n}=12)$ (Figure $8 \mathrm{~A})$. Higher DJ-1 protein levels were associated with increased mortality (Figure $8 \mathrm{~B}$ ), documented bacteremia (Figure $8 \mathrm{C}$ ), and higher multiorgan dysfunction scores on day of study enrollment (Figure 8D). Specific components of the multiorgan dysfunction score also showed significant correlations with DJ-1 levels (see Figure E9). Collectively, these findings indicate DJ-1 is a potent antioxidant that plays a critical role in human sepsis and clinical outcomes.

\section{Discussion}

Our findings reveal a role for DJ-1 in the innate immune response to bacterial sepsis and pathogen clearance. Patients with sepsis who die or develop significant organ dysfunction have increased circulating DJ-1. Absence of DJ-1 in vitro and in vivo resulted in increased ROS and inflammatory mediator expression. Despite an increased proinflammatory and prooxidant state, DJ-1 deficiency confers striking resistance to polymicrobial sepsis in a resuscitated and antibiotic-treated clinically relevant animal model of sepsis. Even in the absence of antibiotics, absence of DJ-1 protects against polymicrobial sepsis-induced mortality by inducing ROSmediated effective and rapid bacterial clearance. Moreover, adoptive transfer of DJ-1-deficient BMCs can confer resistance to bacterial sepsis to WT mice. Here we demonstrate that in innate immune cells, DJ-1 expression increases after an inflammatory (LPS) or bacterial stimulus. Available DJ- 1 then binds to $\mathrm{p} 47^{\text {phox }}$ disrupting NADPH oxidase complex assembly and/or contributing to Nox2 degradation thereby decreasing ROS production. Phagocytes that lack DJ-1 are consequently more efficient at engulfing and killing bacteria.

Figure 6. (Continued). ( $\mathrm{n}=3-6$ per group; ${ }^{\star \star} P \leqslant 0.01$; two-way analysis of variance). ( $B$, left) Representative Western blot showing increased $\mathrm{p} 47^{\text {phox }}$ and Nox2/gp91 ${ }^{\text {phox }}$ protein expression in DJ-1 ${ }^{-1-}$ BMMs compared with WT BMMs after 24 hours of saline or LPS treatment. (B, right) DJ-1 silencing in WT BMMs using short interfering RNA against DJ-1 (DJ-1 siRNA) increased expression of p47 ${ }^{\text {phox }}$ and Nox2 protein expression 24 hours after LPS administration compared with silencing with control scrambled RNA (ctrl siRNA). (C, left) Representative Western blots showing decreased expression of p4 $7^{\text {phox }}$ and Nox2 (gp91 ${ }^{\text {phox }}$ ) in WT BMMs overexpressing adenovirus DJ-1 vector (Ad-DJ-1) compared with control adenovirus vector (Ad-Ctrl) after 24 hours of saline or LPS treatment. (C, right) Increased expression of $\mathrm{p} 47^{\text {phox }}$ and Nox2 in DJ-1 ${ }^{-1-}$ BMMs is mitigated after reconstitution of DJ-1 levels with Ad-DJ-1 compared with Ad-Ctrl. Gels are normalized to GAPDH expression. (D) Representative Western blot showing anti-p47 ${ }^{\text {phox }}$ immunoprecipitated from WT and DJ-1 ${ }^{-1-}$ BMMs and probed with antiphosphoserine antibody in samples treated for 24 hours with LPS (left) and 4 hours with Escherichia coli bacteria (EB) (right). (E) Representative Western blot showing anti-DJ-1 and negative control (NC) IgG immunoprecipitated (IP) from WT BMMs (left) or RAW 264.7 cells (right) and probed with anti-p47 phox , p67 phox , or Nox2 antibody in 24-hour control- or LPS-treated samples. $\left(F\right.$, left) Representative Western blot expression of Nox2 and $\mathrm{p} 47^{\text {phox }}$ protein over time $(0-4 \mathrm{~h})$ in EB-treated samples after pretreatment with cyclohexamide (CHX, $10 \mu \mathrm{g} / \mathrm{ml})$. ( $F$, right) Anti-ubiquitin protein ligase E3 component $\mathrm{n}$-recognin 7 (UBR7) immunoprecipitated from WT and DJ-1 ${ }^{-/-}$ BMMs and probed with anti-Nox2 antibody in samples treated with EB with and without CHX at 4 hours. (G) Representative Western blot showing UBR7 immunoprecipitated from WT and DJ-1 $1^{-1-}$ BMM lysates treated with EB for 4 hours and probed with anti-Nox2 antibody or reciprocal blot showing Nox2 immunoprecipitated from cell samples and probed with UBR7. (H) Representative Western blot showing Nox2 protein expression at 4 hours with EB-treated samples with and without pretreatment of $\mathrm{CHX}(10 \mu \mathrm{g} / \mathrm{ml})$ and proteasomal inhibitor MG132 (10 $\mu \mathrm{M})$. 
A

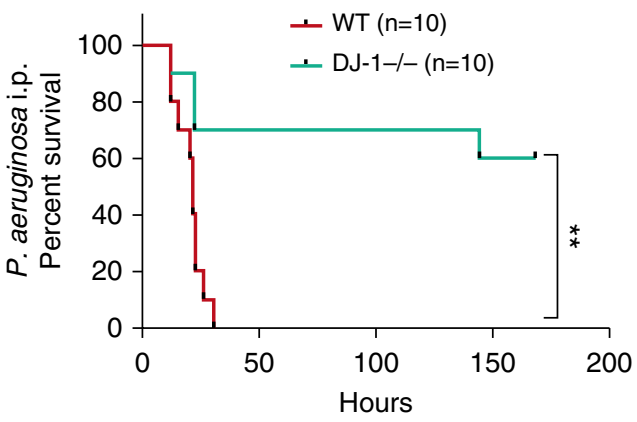

B

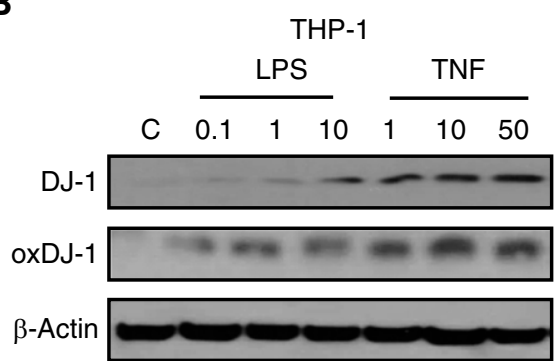

D

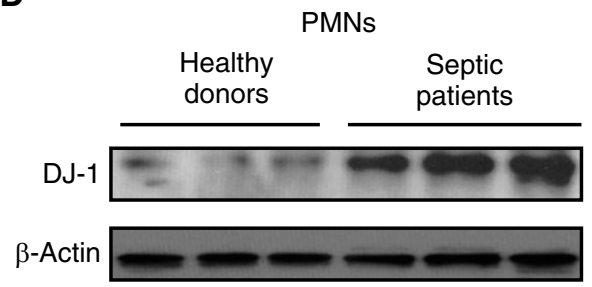

C

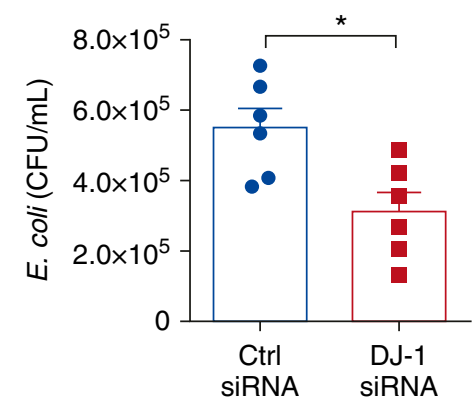

E

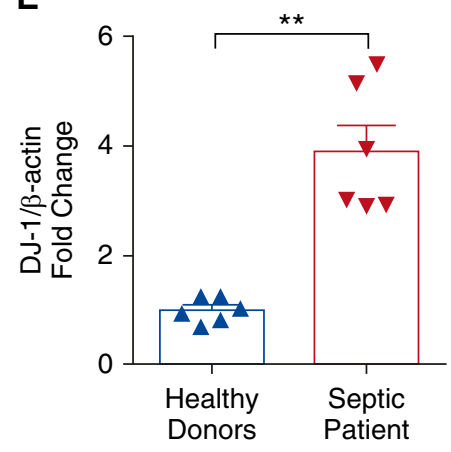

PMA activated THP- 1 cells

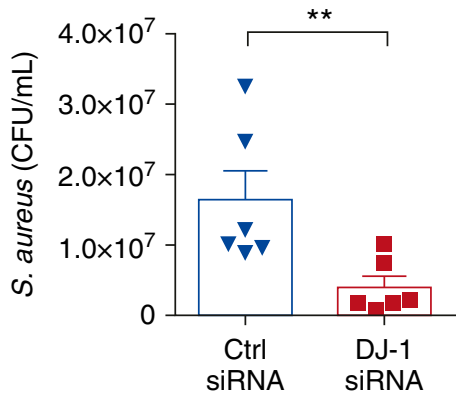

$\mathbf{F}$

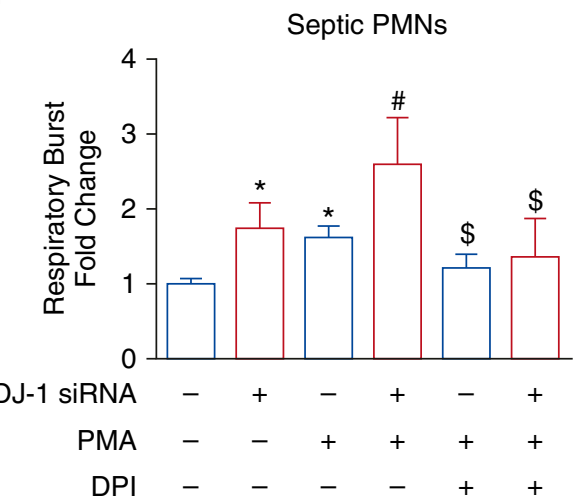

Figure 7. DJ-1 expression modulates bacterial killing and respiratory burst in human phagocytes. $(A)$ Percent survival of wild-type $(\mathrm{WT})$ and DJ-1 ${ }^{-/-}$mice at 7 days with fluid resuscitation and buprenorphine ${ }^{* \star} P \leqslant 0.01$; log-rank/Mantel-Cox test) after intraperitoneal (i.p.) injection of $P$ seudomonas aeruginosa infection. (B) Representative Western blot showing increased DJ-1 and oxDJ-1 protein expression in THP-1 cells with increasing concentration of LPS $(0.1-10 \mu \mathrm{g} / \mathrm{ml}$ ) and tumor necrosis factor (TNF; $1-50 \mathrm{ng} / \mathrm{ml}$ ) stimulation normalized to $\beta$-actin protein expression. (C) Measurement of bacterial killing activity in phorbol 12-myristate 13-acetate (PMA)-activated human monocytic (THP-1) cells with control siRNA or DJ-1 siRNA by gentamicin protection assay at 60 minutes after Escherichia coli or Staphylococcus aureus infection. Data are presented as means \pm SEM $\left(n=5\right.$ per group; ${ }^{*} P \leqslant 0.05 ;{ }^{* \star} P \leqslant 0.01$; analysis of variance). ( $D$ and $E$ ) Representative Western blot and quantification showing increased DJ-1 protein expression in polymorphonuclear cells (PMNs) collected from healthy donors or patients with sepsis normalized to $\beta$-actin protein expression (*^ $P \leqslant 0.01)$. ( $F$ ) Respiratory burst in septic PMNs at 24 hours transfected with control or DJ-1 siRNA at baseline (no treatment), or after treatment with PMA, or 1 hour pretreatment with diphenyleneiodonium (DPI). Data are presented means \pm SEM $\left(n=5\right.$ per group; ${ }^{\star} P \leqslant 0.05$ compared with control baseline; ${ }^{\#} P \leqslant 0.05$ compared with DJ-1 baseline; ${ }^{\$} P \leqslant 0.05$ compared with groups treated with PMA only for respective genotypes). CFU = colony-forming unit; Ctrl= control; siRNA = short interfering RNA.

Regulating ROS balance is vital for mounting an appropriate immune response without excessive oxidative damage to resident host tissues. In macrophages and neutrophils, bacterial phagocytosis results in NADPH oxidase 2 complex assembly at the phagosomal membrane. Membrane (gp91 ${ }^{\text {phox }} /$ Nox 2 and $\left.\mathrm{p} 22^{\text {phox }}\right)$ and cytosolic ( $447^{\text {phox }}, \mathrm{p} 67^{\text {phox }}$, $\mathrm{p} 40^{\text {phox }}$, and Rac1) subunits come together leading to an activated complex capable of generating ROS (46). Generation of ROS (specifically superoxide) constitutes a fundamental pathway for pathogen clearance $(31,46-48)$. In this study, we demonstrate that DJ-1 expression impairs host defense against bacterial infection by substantially limiting ROS production by the NADPH oxidase complex. DJ-1-deficient BMMs had enhanced expression and activity 
A

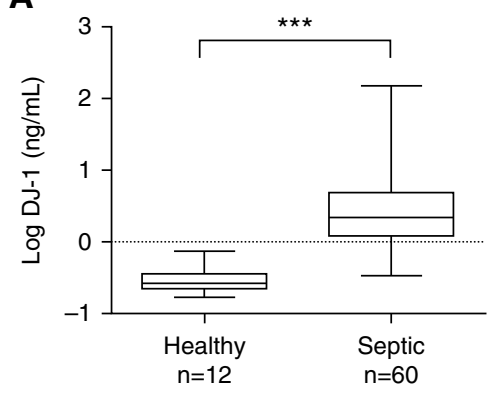

C

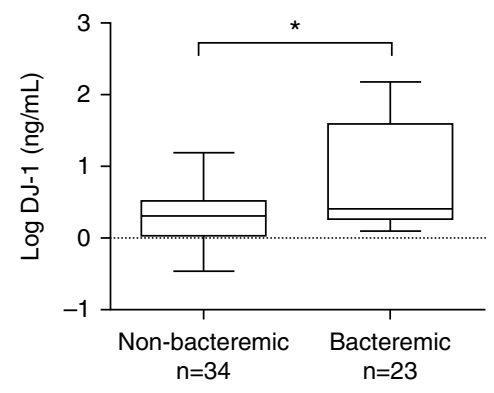

E

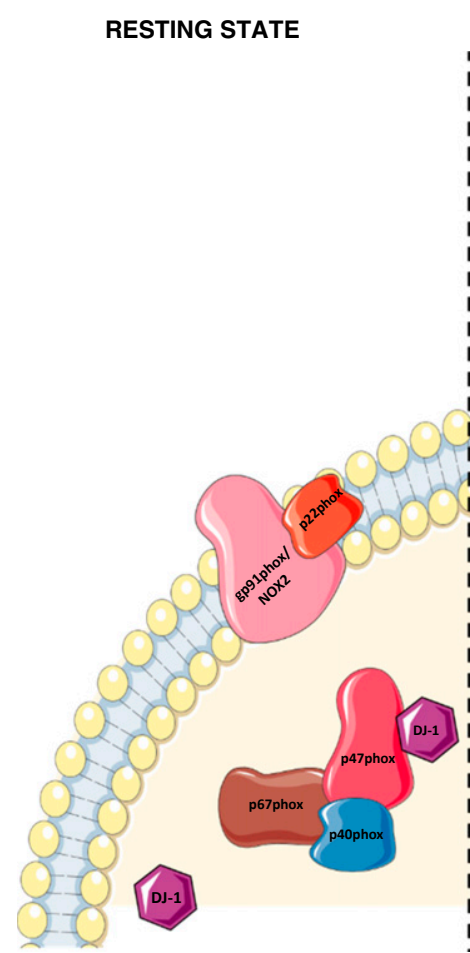

B

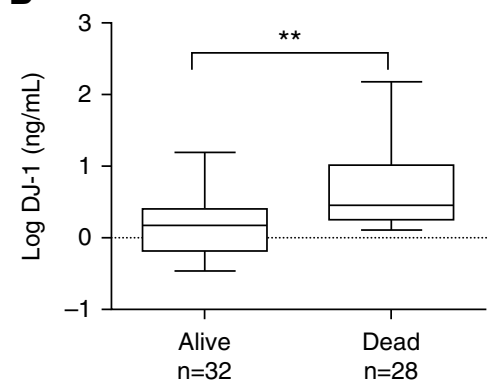

D

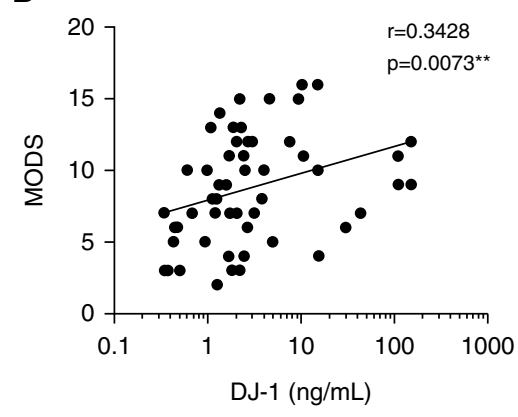

ACTIVE STATE Microbial, Inflammatory Stimuli

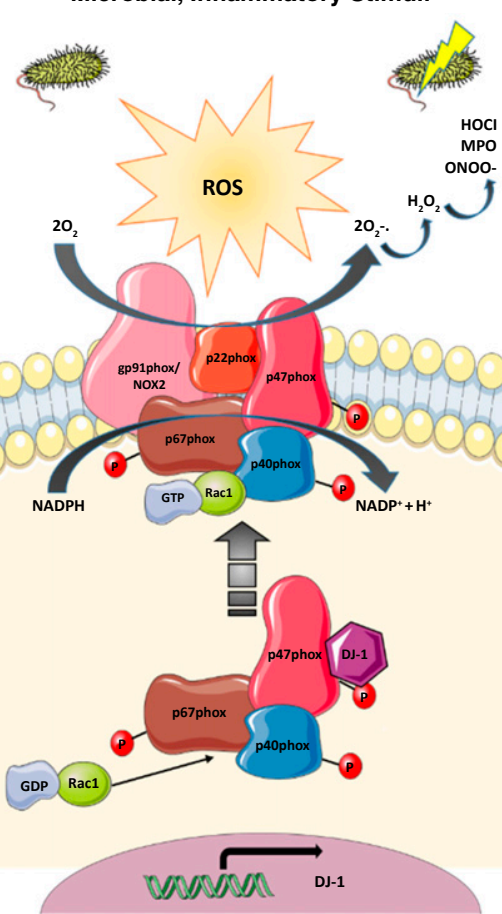

CELLULAR FEEDBACK

Redox Response

Figure 8. DJ-1 protein expression in patients with sepsis. Plasma DJ-1 protein level (log $\mathrm{ng} / \mathrm{ml})$ was increased in $(A)$ patients with sepsis $(\mathrm{n}=60)$ versus control subjects without sepsis $(n=12),(B)$ patients with severe sepsis who died $(n=32)$ compared with those alive at 28 days $(n=28)$, and $(C)$ patients without $(n=34)$ and with documented bacteremia $(n=23)$. Data are presented as means \pm SEM $\left({ }^{\star} P \leqslant 0.05 ;{ }^{\star \star} P \leqslant 0.01 ;{ }^{\star \star \star} P \leqslant 0.001 ;\right.$ Mann-Whitney test). (D) Correlation analysis of plasma DJ-1 levels with enrollment multiorgan dysfunction score (MODS). (E) Schematic of DJ-1 role in regulating NADPH oxidase and bacteria clearance. In innate immune cells, after an inflammatory (LPS) or bacterial stimulus, DJ-1 expression is increased. Available DJ-1 can directly scavenge superoxide ions and reduce reactive oxygen species (ROS). Alternatively, DJ-1 may bind to p47 $7^{\text {phox }}$, thereby disrupting NADPH oxidase complex assembly, or ubiquitinate Nox2, subsequently leading to decreased ROS production. MPO = myeloperoxidase. 
of the NOX complex. DJ-1 has been previously shown to regulate Nox4 in renal proximal tubule cells (49), further reinforcing the critical role of DJ-1 in regulating redox status in cells. Moreover, here absence of DJ-1 also results in decreased expression of Nrf2-dependent genes. This is in keeping with our previous data showing DJ-1 protects Nrf2 from Keap-1-mediated degradation (43).

In addition to the NADPH oxidase, the mitochondrial electron transport chain is an alternative contributor of ROS. Mitochondrial ROS are recognized as critical in innate immune activation and facilitation of antibacterial activity $(50,51)$. ROS emission per unit $\mathrm{O}_{2}$ consumed is highest when OXPHOS flux is lowest, because membrane potential is high. Our observations of impaired cellular bioenergetics in $\mathrm{DJ}-1^{-1-}$ BMMs are consistent with previous findings $(52,53)$. In our study, treatment with Bay-11 7082 (specific inhibitor of inflammasome activation in macrophages) and mitoTEMPO (to reduce mtROS) seems to reverse the enhanced phagocytosis observed in the DJ-1 ${ }^{-1-}$ BMMs. Possible crosstalk between mitochondrial ROS and NADPH oxidant generation may contribute to a positive ROS feedback loop in $\mathrm{DJ}-1^{-/-}$mice $(26,54)$.

Most studies to date have focused on the role of DJ-1 as an ROS scavenger $(55,56)$. DJ-1, however, has a variety of other functions including protein chaperone, protease, RNA binding, and regulator of autophagy $(17,18,20,52$, $57-62)$. It is unclear whether multiple or specific functions of DJ-1 are also involved. In addition to its intracellular functions, DJ-1 is secreted into extracellular regions $(63,64)$ but its extracellular role remains enigmatic. Further studies will elucidate the role of extracellular DJ-1 in sepsis.

The role of DJ-1 in the host immune response has only been recently recognized. DJ-1 $1^{-/-}$mice exhibit augmented passive cutaneous anaphylactic reactions and antigen-stimulated mast cell degranulation (65) suggesting a role for DJ-1 in adaptive immune response modulation. In addition, $\mathrm{CD} 3^{-/-}$T-cell migration is increased in DJ-1 ${ }^{-1-}$ mice. DJ-1 ${ }^{-1-}$ Th1 and Th17 $\mathrm{CD}^{+}$T-cell subsets had increased production of IFN- $\gamma$ and IL-17 (66). Lack of DJ-1 leads to enhanced ROS production, higher Sgk1 (serine/threonine-protein kinase Sgk1 or serum glucocorticoidregulated kinase 1) expression, and development of regulatory $\mathrm{T}$ cells (67). DJ-1 deficiency modifies the $\mathrm{CD} 4^{+} / \mathrm{CD} 8^{+}$ $\mathrm{T}$-cell ratio (67). These data are in keeping with our findings that absence of DJ-1 promotes early M1 polarization. We speculate that the enhanced bacterial killing phenotype conferred by DJ-1 deficiency may be one explanation for the conservation of this mutation through evolution.

Our results differ from those of a recent report that $\mathrm{DJ}-1$ binding to $\mathrm{p} 47^{\text {phox }}$ is required for NADPH oxidasedependent ROS production (28). However, those findings are surprising given the well-established antioxidant role of DJ-1 highlighting increased ROS and proinflammatory markers in various DJ-1-deficient models of inflammation $(25,40,49,58,68)$. DJ-1-deficient astrocytes, for instance, have increased ROS, IL-6, and iNOS after LPS stimulation (69). Likewise, bone marrow-derived mast cells and mice lacking DJ-1 have higher ROS and TNF levels after DNP-specific IgE stimulation (65). These findings and the consistency of our in vivo and in vitro data establish DJ-1 as a negative regulator of ROS production with implications for host immunity $(70,71)$. Here we show that binding of DJ-1 to $\mathrm{p} 47^{\text {phox }}$ acts to inhibit $\mathrm{p} 47^{\text {phox }}$ phosphorylation, preventing subsequent activation of the complex and ROS production. Phosphorylation of $\mathrm{p} 47^{\text {phox }}$ is a key event in the assembly and translocation of the cytosolic components as well as the activation of the NOX complex $(45,72)$. Furthermore, in the absence of DJ-1, Nox2 ubiquitination was reduced after exposure to LPS or E. coli bacteria, suggesting that DJ-1 regulates the stability of the NADPH oxidase protein. Treating cells with the proteasome inhibitor MG132 prevented Nox2 degradation in DJ-1 competent BMMs. A schematic diagram of our proposed mechanism is presented in Figure 8E.

Importantly, human monocytes and PMNs from patients with sepsis can be made more efficient in bacterial phagocytosis and killing by transfection with an anti-DJ-1 siRNA. Based on our findings, DJ-1 contributes to a critical cell protection negative feedback mechanism to prevent excessive oxidative stress and inflammation. Reduced ROS production, however, significantly affects bacterial killing and clearance resulting in early mortality from bacterial sepsis. Interestingly, deletion of other negative regulators of ROS and innate immune signaling, such as NRROS, KLF, and ATF3, also results in improved outcomes in acute bacterial infection models $(70,73,74)$. Here we also highlight how targeting endogenous mechanisms to maximize early clearance of bacteria may be beneficial for host survival. Collectively, our results challenge the paradigm that morbidity/mortality are determined by degree or severity of inflammation alone. These findings demonstrate dissociation between sepsis outcomes (organ injury and death) and inflammation. They also emphasize that therapeutic strategies designed to simply decrease ROS and inflammation in early sepsis may be ultimately detrimental. This is in accordance with the current Sepsis-3 definition, which emphasizes the need to screen and identify underlying infection, and to distinguish infection-related organ dysfunction from that of noninfectious insults, such as trauma and burns (75).

In summary, our data show that loss of DJ-1 enhances ROS, inflammatory responses, and bacterial clearance, resulting in improved survival from CLP-induced sepsis. DJ-1 binds to the NADPH oxidase complex affecting its stability and its ROSgenerating capacity, thereby impairing optimal ROS production for bacterial clearance. Furthermore, these observations provide novel insights into the host response during systemic bacterial infection that challenges the conventional paradigm that outcomes in sepsis are primarily determined by the severity of the host inflammatory response.

Author disclosures are available with the tex of this article at www.atsjournals.org.

Acknowledgment: The authors thank Dr. David Park (University of Ottawa) for the DJ-1 adenovirus vector and Julie Khang (University of Toronto) for her help with the multiplex cytokine assays. 


\section{References}

1. Angus DC, Linde-Zwirble WT, Lidicker J, Clermont G, Carcillo J, Pinsky MR. Epidemiology of severe sepsis in the United States: analysis of incidence, outcome, and associated costs of care. Crit Care Med 2001;29:1303-1310.

2. Angus DC, Mira JP, Vincent JL. Improving clinical trials in the critically ill. Crit Care Med 2010;38:527-532.

3. Annane D. Improving clinical trials in the critically ill: unique challengesepsis. Crit Care Med 2009;37(Suppl. 1):S117-S128.

4. Dellinger RP, Levy MM, Carlet JM, Bion J, Parker MM, Jaeschke R, Reinhart K, Angus DC, Brun-Buisson C, Beale R, et al.; International Surviving Sepsis Campaign Guidelines Committee; American Association of Critical-Care Nurses; American College of Chest Physicians; American College of Emergency Physicians; Canadian Critical Care Society; European Society of Clinical Microbiology and Infectious Diseases; European Society of Intensive Care Medicine; European Respiratory Society; International Sepsis Forum; Japanese Association for Acute Medicine; Japanese Society of Intensive Care Medicine; Society of Critical Care Medicine; Society of Hospital Medicine; Surgical Infection Society; World Federation of Societies of Intensive and Critical Care Medicine. Surviving Sepsis Campaign: international guidelines for management of severe sepsis and septic shock: 2008. Crit Care Med 2008;36:296-327.

5. Marshall JC, Maier RV, Jimenez M, Dellinger EP. Source control in the management of severe sepsis and septic shock: an evidence-based review. Crit Care Med 2004;32(Suppl. 11):S513-S526.

6. Hackett CJ. Innate immune activation as a broad-spectrum biodefense strategy: prospects and research challenges. J Allergy Clin Immunol 2003;112:686-694.

7. Nathan C. Points of control in inflammation. Nature 2002;420:846-852.

8. London NR, Zhu W, Bozza FA, Smith MC, Greif DM, Sorensen LK, Chen L, Kaminoh Y, Chan AC, Passi SF, et al. Targeting Robo4-dependent Slit signaling to survive the cytokine storm in sepsis and influenza. Sci Transl Med 2010;2:23ra19.

9. Mei SH, Haitsma JJ, Dos Santos CC, Deng Y, Lai PF, Slutsky AS, Liles WC, Stewart DJ. Mesenchymal stem cells reduce inflammation while enhancing bacterial clearance and improving survival in sepsis. Am J Respir Crit Care Med 2010;182:1047-1057.

10. Gupta N, Su X, Popov B, Lee JW, Serikov V, Matthay MA. Intrapulmonary delivery of bone marrow-derived mesenchymal stem cells improves survival and attenuates endotoxin-induced acute lung injury in mice. J Immunol 2007;179:1855-1863.

11. Németh K, Leelahavanichkul A, Yuen PS, Mayer B, Parmelee A, Doi K, Robey PG, Leelahavanichkul K, Koller BH, Brown JM, et al. Bone marrow stromal cells attenuate sepsis via prostaglandin $\mathrm{E}(2)-$ dependent reprogramming of host macrophages to increase their interleukin-10 production. Nat Med 2009;15:42-49.

12. Xu J, Qu J, Cao L, Sai Y, Chen C, He L, Yu L. Mesenchymal stem cellbased angiopoietin-1 gene therapy for acute lung injury induced by lipopolysaccharide in mice. J Pathol 2008;214:472-481.

13. Krasnodembskaya A, Song Y, Fang X, Gupta N, Serikov V, Lee JW, Matthay MA. Antibacterial effect of human mesenchymal stem cells is mediated in part from secretion of the antimicrobial peptide LL-37. Stem Cells 2010;28:2229-2238.

14. dos Santos CC, Murthy S, Hu P, Shan Y, Haitsma JJ, Mei SH, Stewart DJ, Liles WC. Network analysis of transcriptional responses induced by mesenchymal stem cell treatment of experimental sepsis. Am J Pathol 2012;181:1681-1692.

15. Nagakubo D, Taira $T$, Kitaura $H$, Ikeda $M$, Tamai $K$, Iguchi-Ariga SM, Ariga $\mathrm{H}$. DJ-1, a novel oncogene which transforms mouse NIH3T3 cells in cooperation with ras. Biochem Biophys Res Commun 1997; 231:509-513.

16. Clements CM, McNally RS, Conti BJ, Mak TW, Ting JP. DJ-1, a cancerand Parkinson's disease-associated protein, stabilizes the antioxidant transcriptional master regulator Nrf2. Proc Natl Acad Sci USA 2006;103:15091-15096.

17. Kato I, Maita H, Takahashi-Niki K, Saito Y, Noguchi N, Iguchi-Ariga SM, Ariga $\mathrm{H}$. Oxidized DJ-1 inhibits $\mathrm{p} 53$ by sequestering p53 from promoters in a DNA-binding affinity-dependent manner. Mol Cell Biol 2013;33:340-359.
18. Kim RH, Peters M, Jang Y, Shi W, Pintilie M, Fletcher GC, DeLuca C, Liepa J, Zhou L, Snow B, et al. DJ-1, a novel regulator of the tumor suppressor PTEN. Cancer Cell 2005;7:263-273.

19. Klawitter J, Klawitter J, Agardi E, Corby K, Leibfritz D, Lowes BD, Christians U, Seres T. Association of DJ-1/PTEN/AKT- and ASK1/p38-mediated cell signalling with ischaemic cardiomyopathy. Cardiovasc Res 2013;97:66-76.

20. Niki T, Takahashi-Niki K, Taira T, Iguchi-Ariga SM, Ariga H. DJBP a novel DJ-1-binding protein, negatively regulates the androgen receptor by recruiting histone deacetylase complex, and DJ-1 antagonizes this inhibition by abrogation of this complex. Mol Cancer Res 2003;1:247-261.

21. Shinbo Y, Taira T, Niki T, Iguchi-Ariga SM, Ariga H. DJ-1 restores p53 transcription activity inhibited by Topors/p53BP3. Int J Oncol 2005; 26:641-648.

22. Zhong N, Kim CY, Rizzu P, Geula C, Porter DR, Pothos EN, Squitieri F, Heutink $P, X u$ J. DJ-1 transcriptionally up-regulates the human tyrosine hydroxylase by inhibiting the sumoylation of pyrimidine tract-binding protein-associated splicing factor. J Biol Chem 2006; 281:20940-20948.

23. Bonifati V, Rizzu P, van Baren MJ, Schaap O, Breedveld GJ, Krieger E, Dekker MC, Squitieri F, Ibanez $\mathrm{P}$, Joosse $\mathrm{M}$, et al. Mutations in the DJ-1 gene associated with autosomal recessive early-onset parkinsonism. Science 2003;299:256-259.

24. Bandopadhyay R, Kingsbury AE, Cookson MR, Reid AR, Evans IM, Hope AD, Pittman AM, Lashley T, Canet-Aviles R, Miller DW, et al. The expression of DJ-1 (PARK7) in normal human CNS and idiopathic Parkinson's disease. Brain 2004;127:420-430.

25. Taira T, Saito Y, Niki T, Iguchi-Ariga SM, Takahashi K, Ariga H. DJ-1 has a role in antioxidative stress to prevent cell death. EMBO Rep 2004:5:213-218.

26. Canet-Avilés RM, Wilson MA, Miller DW, Ahmad R, McLendon C, Bandyopadhyay S, Baptista MJ, Ringe D, Petsko GA, Cookson MR. The Parkinson's disease protein DJ-1 is neuroprotective due to cysteine-sulfinic acid-driven mitochondrial localization. Proc Natl Acad Sci USA 2004;101:9103-9108.

27. Zhang L, Shimoji M, Thomas B, Moore DJ, Yu SW, Marupudi NI, Torp R, Torgner IA, Ottersen OP, Dawson TM, et al. Mitochondrial localization of the Parkinson's disease related protein DJ-1: implications for pathogenesis. Hum Mol Genet 2005;14:2063-2073.

28. Liu W, Wu H, Chen L, Wen Y, Kong X, Gao WQ. Park7 interacts with p47(phox) to direct NADPH oxidase-dependent ROS production and protect against sepsis. Cell Res 2015;25:691-706.

29. Alonso de Vega JM, Díaz J, Serrano E, Carbonell LF. Oxidative stress in critically ill patients with systemic inflammatory response syndrome. Crit Care Med 2002;30:1782-1786.

30. Kong X, Thimmulappa R, Craciun F, Harvey C, Singh A, Kombairaju P, Reddy SP, Remick D, Biswal S. Enhancing Nrf2 pathway by disruption of Keap1 in myeloid leukocytes protects against sepsis. Am J Respir Crit Care Med 2011;184:928-938.

31. Marriott HM, Jackson LE, Wilkinson TS, Simpson AJ, Mitchell TJ, Buttle DJ, Cross SS, Ince PG, Hellewell PG, Whyte MK, et al. Reactive oxygen species regulate neutrophil recruitment and survival in pneumococcal pneumonia. Am J Respir Crit Care Med 2008;177: 887-895.

32. Pizzolla A, Hultqvist M, Nilson B, Grimm MJ, Eneljung T, Jonsson IM, Verdrengh M, Kelkka T, Gjertsson I, Segal BH, et al. Reactive oxygen species produced by the NADPH oxidase 2 complex in monocytes protect mice from bacterial infections. J Immunol 2012;188: 5003-5011.

33. Cornejo Castro EM, Waak J, Weber SS, Fiesel FC, Oberhettinger $P$, Schütz M, Autenrieth IB, Springer W, Kahle PJ. Parkinson's diseaseassociated DJ-1 modulates innate immunity signaling in Caenorhabditis elegans. J Neural Transm (Vienna) 2010;117: 599-604.

34. Huang M, Liu Y, Xie C, Wang WN. LvDJ-1 plays an important role in resistance against Vibrio alginolyticus in Litopenaeus vannamei. Fish Shellfish Immunol 2015;44:180-186.

35. Amatullah $\mathrm{H}$, Shan $\mathrm{Y}$, Gali $\mathrm{P}$, Beauchamps B, Maron-Gutierrez T, Zhou DY, Tsang J, Mei S, Haitsma JJ, Mak TW, et al. Absence of DJ-1 attenuates morbidity and mortality in experimental sepsis through 
improved bacterial clearance. Presented at the ESICM LIVES 2013 26th Annual Congress. October 7, 2013, Paris.

36. Amatullah H, Shan Y, Gali P, Beauchamps B, Maron-Gutierrez T, Zhou DY, Tsang J, Mei S, Haitsma JJ, Mak TW, et al. Targeted deletion of DJ-1 attenuates morbidity and mortality in polymicrobial model of sepsis through enhanced clearance of bacteria. Presented at the Canadian Critical Care Forum. November 11, 2013, Toronto.

37. Amatullah H, Shan Y, Gali PL, Beauchamps B, Maron-Gutierrez T, Zhou DY, Tsang J, Mei S, Haitsma JJ, Mak TW, et al. Targeted deletion of DJ-1 reveals its fundamental role in regulation of autophagic bacterial clearance and outcomes in experimental sepsis [abstract]. Am J Respir Crit Care Med 2014;189:A1643.

38. Ricciuto DR, dos Santos CC, Hawkes M, Toltl LJ, Conroy AL, Rajwans N, Lafferty El, Cook DJ, Fox-Robichaud A, Kahnamoui K, et al. Angiopoietin-1 and angiopoietin-2 as clinically informative prognostic biomarkers of morbidity and mortality in severe sepsis. Crit Care Med 2011;39:702-710.

39. Jia SH, Li Y, Parodo J, Kapus A, Fan L, Rotstein OD, Marshall JC. Pre-B cell colony-enhancing factor inhibits neutrophil apoptosis in experimental inflammation and clinical sepsis. J Clin Invest 2004; 113:1318-1327.

40. Kim RH, Smith PD, Aleyasin H, Hayley S, Mount MP, Pownall S, Wakeham A, You-Ten AJ, Kalia SK, Horne P, et al. Hypersensitivity of DJ-1-deficient mice to 1-methyl-4-phenyl-1,2,3,6-tetrahydropyrindine (MPTP) and oxidative stress. Proc Natl Acad Sci USA 2005;102: 5215-5220.

41. dos Santos CC, Gattas DJ, Tsoporis JN, Smeding L, Kabir G, Masoom H, Akram A, Plotz F, Slutsky AS, Husain M, et al. Sepsis-induced myocardial depression is associated with transcriptional changes in energy metabolism and contractile related genes: a physiological and gene expression-based approach. Crit Care Med 2010;38: 894-902.

42. Smeding L, Leong-Poi H, Hu P, Shan Y, Haitsma JJ, Horvath E, Furmli S, Masoom H, Kuiper JW, Slutsky AS, et al. Salutary effect of resveratrol on sepsis-induced myocardial depression. Crit Care Med 2012;40:1896-1907.

43. Shan Y, Akram A, Amatullah H, Zhou DY, Gali PL, Maron-Gutierrez T, González-López A, Zhou L, Rocco PR, Hwang D, et al. ATF3 protects pulmonary resident cells from acute and ventilator-induced lung injury by preventing Nrf2 degradation. Antioxid Redox Signal 2015;22:651-668.

44. Malam Z, Parodo J, Waheed F, Szaszi K, Kapus A, Marshall JC. Pre-B cell colony-enhancing factor (PBEF/Nampt/visfatin) primes neutrophils for augmented respiratory burst activity through partial assembly of the NADPH oxidase. $J$ Immunol 2011;186:6474-6484.

45. El-Benna J, Dang PM, Gougerot-Pocidalo MA, Marie JC, BrautBoucher F. p47phox, the phagocyte NADPH oxidase/NOX2 organizer: structure, phosphorylation and implication in diseases. Exp Mol Med 2009;41:217-225.

46. Huang J, Canadien V, Lam GY, Steinberg BE, Dinauer MC, Magalhaes MA, Glogauer M, Grinstein S, Brumell JH. Activation of antibacterial autophagy by NADPH oxidases. Proc Natl Acad Sci USA 2009;106: 6226-6231.

47. Gao XP, Standiford TJ, Rahman A, Newstead M, Holland SM, Dinauer MC, Liu QH, Malik AB. Role of NADPH oxidase in the mechanism of lung neutrophil sequestration and microvessel injury induced by gramnegative sepsis: studies in p47phox-/- and gp91phox-/- mice. $J$ Immunol 2002;168:3974-3982.

48. Sareila O, Kelkka T, Pizzolla A, Hultqvist M, Holmdahl R. NOX2 complex-derived ROS as immune regulators. Antioxid Redox Signal 2011;15:2197-2208.

49. Cuevas S, Zhang Y, Yang Y, Escano C, Asico L, Jones JE, Armando I, Jose PA. Role of renal DJ-1 in the pathogenesis of hypertension associated with increased reactive oxygen species production. Hypertension 2012;59:446-452.

50. Zhou R, Yazdi AS, Menu P, Tschopp J. A role for mitochondria in NLRP3 inflammasome activation. Nature 2011;469:221-225.

51. West AP, Shadel GS, Ghosh S. Mitochondria in innate immune responses. Nat Rev Immunol 2011;11:389-402.
52. Heo JY, Park JH, Kim SJ, Seo KS, Han JS, Lee SH, Kim JM, Park JI, Park SK, Lim K, et al. DJ-1 null dopaminergic neuronal cells exhibit defects in mitochondrial function and structure: involvement of mitochondrial complex I assembly. PLoS One 2012;7:e32629.

53. Irrcher I, Aleyasin H, Seifert EL, Hewitt SJ, Chhabra S, Phillips M, Lutz AK, Rousseaux MW, Bevilacqua L, Jahani-Asl A, et al. Loss of the Parkinson's disease-linked gene DJ-1 perturbs mitochondrial dynamics. Hum Mol Genet 2010;19:3734-3746.

54. Kroller-Schon S, Steven S, Kossmann S, Scholz A, Daub S, Oelze M, Xia N, Hausding M, Mikhed Y, Zinssius E, et al. Molecular mechanisms of the crosstalk between mitochondria and NADPH oxidase through reactive oxygen species-studies in white blood cells and in animal models. Antioxid Redox Signal 2014;20:247-266.

55. Kinumi T, Kimata J, Taira T, Ariga H, Niki E. Cysteine-106 of DJ-1 is the most sensitive cysteine residue to hydrogen peroxide-mediated oxidation in vivo in human umbilical vein endothelial cells. Biochem Biophys Res Commun 2004;317:722-728.

56. Zhou W, Zhu M, Wilson MA, Petsko GA, Fink AL. The oxidation state of DJ-1 regulates its chaperone activity toward alpha-synuclein. $J \mathrm{Mol}$ Biol 2006;356:1036-1048.

57. Andres-Mateos E, Perier C, Zhang L, Blanchard-Fillion B, Greco TM, Thomas B, Ko HS, Sasaki M, Ischiropoulos H, Przedborski S, et al. DJ-1 gene deletion reveals that DJ-1 is an atypical peroxiredoxin-like peroxidase. Proc Natl Acad Sci USA 2007;104: 14807-14812.

58. Billia F, Hauck L, Grothe D, Konecny F, Rao V, Kim RH, Mak TW. Parkinson-susceptibility gene DJ-1/PARK7 protects the murine heart from oxidative damage in vivo. Proc Natl Acad Sci USA 2013;110: 6085-6090.

59. Chen J, Li L, Chin LS. Parkinson disease protein DJ-1 converts from a zymogen to a protease by carboxyl-terminal cleavage. Hum $\mathrm{Mol}$ Genet 2010;19:2395-2408.

60. McCoy MK, Cookson MR. DJ-1 regulation of mitochondrial function and autophagy through oxidative stress. Autophagy 2011;7: 531-532.

61. Ren H, Fu K, Mu C, Li B, Wang D, Wang G. DJ-1, a cancer and Parkinson's disease associated protein, regulates autophagy through JNK pathway in cancer cells. Cancer Lett 2010;297: 101-108.

62. Takahashi K, Taira T, Niki T, Seino C, Iguchi-Ariga SM, Ariga H. DJ-1 positively regulates the androgen receptor by impairing the binding of PIASx alpha to the receptor. J Biol Chem 2001;276:37556-37563.

63. Tsuboi $\mathrm{Y}$, Munemoto H, Ishikawa S, Matsumoto K, Iguchi-Ariga SM, Ariga H. DJ-1, a causative gene product of a familial form of Parkinson's disease, is secreted through microdomains. FEBS Lett 2008;582:2643-2649.

64. Waragai M, Nakai M, Wei J, Fujita M, Mizuno H, Ho G, Masliah E, Akatsu $H$, Yokochi F, Hashimoto M. Plasma levels of DJ-1 as a possible marker for progression of sporadic Parkinson's disease. Neurosci Lett 2007;425:18-22.

65. Kim DK, Kim HS, Kim AR, Kim JH, Kim B, Noh G, Kim HS, Beaven MA Kim YM, Choi WS. DJ-1 regulates mast cell activation and IgEmediated allergic responses. J Allergy Clin Immunol 2013;13: 1653-1662.

66. Jung SH, Won KJ, Lee KP, Lee DH, Yu S, Lee DY, Seo EH, Kang H, Park ES, Kim HJ, et al. DJ-1 protein regulates CD3+ T cell migration via overexpression of CXCR4 receptor. Atherosclerosis 2014;235:503-509.

67. Singh Y, Chen H, Zhou Y, Föller M, Mak TW, Salker MS, Lang F. Differential effect of DJ-1/PARK7 on development of natural and induced regulatory T cells. Sci Rep 2015;5:17723.

68. Aleyasin H, Rousseaux MW, Phillips M, Kim RH, Bland RJ, Callaghan S, Slack RS, During MJ, Mak TW, Park DS. The Parkinson's disease gene DJ-1 is also a key regulator of stroke-induced damage. Proc Natl Acad Sci USA 2007;104:18748-18753.

69. Waak J, Weber SS, Waldenmaier A, Görner K, Alunni-Fabbroni M, Schell H, Vogt-Weisenhorn D, Pham TT, Reumers V, Baekelandt V, et al. Regulation of astrocyte inflammatory responses by the Parkinson's disease-associated gene DJ-1. FASEB J 2009;23: 2478-2489. 
70. Noubade R, Wong K, Ota N, Rutz S, Eidenschenk C, Valdez PA, Ding J, Peng I, Sebrell A, Caplazi $P$, et al. NRROS negatively regulates reactive oxygen species during host defense and autoimmunity. Nature 2014;509:235-239.

71. Wang G, Abadía-Molina AC, Berger SB, Romero X, O'Keeffe MS, Rojas-Barros DI, Aleman M, Liao G, Maganto-García E, Fresno $\mathrm{M}$, et al. Cutting edge: Slamf8 is a negative regulator of Nox2 activity in macrophages. J Immunol 2012;188: 5829-5832.

72. Babior BM. The activity of leukocyte NADPH oxidase: regulation by p47PHOX cysteine and serine residues. Antioxid Redox Signal 2002; 4:35-38.
73. Hoetzenecker W, Echtenacher B, Guenova E, Hoetzenecker K, Woelbing F, Brück J, Teske A, Valtcheva N, Fuchs K, Kneilling M, et al. ROSinduced ATF3 causes susceptibility to secondary infections during sepsis-associated immunosuppression. Nat Med 2011;18:128-134.

74. Mahabeleshwar GH, Kawanami D, Sharma N, Takami Y, Zhou G, Shi H, Nayak L, Jeyaraj D, Grealy R, White M, et al. The myeloid transcription factor KLF2 regulates the host response to polymicrobial infection and endotoxic shock. Immunity 2011;34:715-728.

75. Singer M, Deutschman CS, Seymour CW, Shankar-Hari M, Annane D, Bauer M, Bellomo R, Bernard GR, Chiche JD, Coopersmith CM, et al. The third international consensus definitions for sepsis and septic shock (Sepsis-3). JAMA 2016;315:801-810. 